\title{
Os Juízes Brasileiros Favorecem a Parte Mais Fraca?'
}

\author{
Brisa Lopes de Mello Ferrão ${ }^{2}$ \\ Ivan César Ribeiro ${ }^{3}$
}

\section{Introdução}

Estudos recentes têm procurado estabelecer a relação entre um melhor ambiente institucional e o desenvolvimento econômico (North, 1990). Nesse sentido, testes empíricos, através de análises cross-country, mostram que países com instituições mais fortes, que asseguram os direitos de propriedade e o cumprimento de contratos, experimentam maiores índices de crescimento do PIB per capita e maiores taxas de investimento interno e externo (Barro, 1991, Mauro, 1993, Knack, Keefer, 1995, Wei, 2000).

\footnotetext{
1 Agradecemos aos professores José Eduardo Campos de Oliveira Faria e Celso Lafer (Faculdade de Direito da Universidade de São Paulo) pela orientação, aos participantes da X Conferência da Associação Latino Americana e Caribenha de Direito e Economia (ALACDE 2006) em Buenos Aires, aos participantes da $10^{*}$ Conferência da International Society for New Institutional Economics (ISNIE 2006) em Boulder e aos participantes do workshop do Ronald Coase Institute, também em Boulder, em especial a Antonio Nicita (Universidade de Siena), Ricardo Ribeiro (Universidade Federal de Pernambuco), John Nye e Alberto Simpser (ambos da Universidade de Chicago) e Décio Zylbersztajn (FEA/ USP) pelas sugestões e críticas às versōes preliminares deste artigo. Agradecemos também aos participantes do I Seminário Estabilidade Econômica e Direito no Rio de Janeiro, em especial aos professores Joaquim Falcão, Edmar Bacha, Armando Castelar Pinheiro, Sérgio Renault, Pierpaolo Bottini e Diego Arguelhes. E finalmente aos professores Denisard Alves (FEA/USP), Walter Belluzzo (FEA Ribeirão) e Edinaldo Tebaldi (CAEN/UFC) pelas discussões quanto ao modelo econométrico.

2 Bacharel e Mestranda em Direito pela FD/USP, Pesquisadora do IDCID, Editora da Review of Economic Development, Public Policy and Law. E-mail: <brisaferrao@usp.br>.

3 Graduado e Mestre em Administração de Empresas (área de Economia de Empresas) pela FEA/USP e graduado em Direito (FD/USP), Editor-Chefe da Review of Economic Development. Public Policy and Law. E-mail: <iribeiro@usp.br>.
} 
A falta de instituições adequadas redunda na proliferação de custos de transação (Coase, 1937), impedindo o perfeito funcionamento do mercado. Isso leva a maiores custos para a contratação, alocaçōes ineficientes dos direitos de propriedade (Coase, 1961), gerando também a necessidade de internalizar atividades na firma além do ponto eficiente. ${ }^{4}$

Dentre as instituiçōes capazes de garantir um melhor desempenho econômico, o Judiciário em especial tem sido objeto de estudos que procuram explicar os determinantes de seu melhor ou pior funcionamento. Esses estudos têm examinado as reformas do sistema judicial, em aspectos como a influência da maior ou menor burocratização, da concentração de poderes nas mãos dos juízes, accountability e outras variáveis (World Bank, 2004, Santiso, 2003, Buscaglia; Dakolias, 1999).

Entre esses aspectos, as dificuldades criadas pelo sistema judicial para retomar a posse de bens financiados e executar garantias, bem como a existência de um viés pró-devedor, são apontadas como prejudiciais à oferta de crédito, tendo como efeito final o aumento do prêmio de risco exigido, do ágio e das taxas de juros praticadas no Brasil (Pinheiro, 2001, 2003, Arida et al., 2004, Laeven; Majnoni, 2003). A influência sobre essas taxas se dá de duas formas: através do aumento do risco de crédito, por resultar no recebimento de uma parcela menor dos financiamentos, e através do aumento das despesas administrativas, ao exigir a manutenção de um corpo jurídico maior, dadas as dificuldades do procedimento judicial (Fachada et al., 2003, p. 8).

A garantia da execução dos contratos de financiamento não afeta apenas as escolhas de investimento dos agentes na economia, mas também a produtividade total dos fatores. Modelos e pesquisas empíricas comparativas mostram que o efeito das garantias jurisdicionais é maior do que o dos custos de intermediação nesse aumento de produtividade (Antunes et al., 2005, Amaral; Quintin, 2004). Segundo Antunes et al. (2005), se nos Estados Unidos o nível de garantia legal dos contratos fosse reduzido para o nível observado no Brasil (uma variação de menos de $50 \%$ no índice de garantia adotado no artigo), o PIB per capita decresceria entre $11 \%$ e $12 \%$, com efeitos também sobre o nível de desigualdade social.

\section{A incerteza jurisdicional}

O conceito de incerteza jurisdicional é expresso por um viés contra o credor (Arida et al., 2005, Lamounier; Souza, 2002), tornando difícil para este executar as garantias contratuais ou revender o crédito. A manifestação desse viés seria comprovada pela disposição dos juízes em afastar o contrato em nome da justiça social. A fonte dessa predisposição contra o credor teria um fundo cultural possível de se observar, por exemplo, na contraposição que se faz no Brasil entre o capital produtivo e o capital especulativo (Arida et al., 2005).

4 Na ausência de garantia da execução de contratos se observará um maior nível de verticalização também para evitar as possibilidades de hold up (Williamson, 1985, 1996). 
Tabela 2

\begin{tabular}{|c|c|c|}
\hline \multicolumn{3}{|c|}{$\begin{array}{l}\text { 1- Opção entre garantir o cumprimento de contratos e busca do justiça social - ponto de vista dos ma- } \\
\text { gistrados. }\end{array}$} \\
\hline $\begin{array}{l}\text { Questāo I - "Na aplicação da lei, existe freqüentemente uma tensão entre con- } \\
\text { tratos, que precisam ser observados, e os interesses de segmentos sociais menos } \\
\text { privilegiados, que precisam ser atendidos. Considerando o conflito que surge nes- } \\
\text { ses casos entre esses dois objetivos, duas posiçōes opostas têm sido defendidas. A. } \\
\text { Os contratos devem ser sempre respeitados, independentemente de suas reper- } \\
\text { cussōes sociais; B. O juiz tem um papel social a cumprir, e a busca da justiça social } \\
\text { justifica decisōes que violem os contratos". }\end{array}$ & Freq & $\%$ \\
\hline Com qual das duas posições o senhor concorda mais? & & \\
\hline Concorda mais com a primeira (A) & 146 & 19,7 \\
\hline Concorda mais com a segunda (B) & 542 & 73,1 \\
\hline Não sabe / sem opiniāo & 21 & 2,8 \\
\hline Nāo respondeu & 32 & 4,3 \\
\hline
\end{tabular}

Fonte: Pinheiro (2002).

Tabela 3

2 - Distribuiçāo das opçōes entre cumprimento de contratos e busca de justiça social por área do direito.

Questāo 2- "Em que tipos de causas, na sua opinião, deve prevalecer a posição A (os contratos devem ser sempre respeitados) ou a posição $B$ (a busca da justiça social às vezes justifica decisóes que violem os contratos) ?"

\begin{tabular}{|c|c|c|c|c|c|c|c|c|}
\hline & & \begin{tabular}{|c|} 
Deve \\
sempre \\
prevalecer \\
a posiçāo \\
A \\
\end{tabular} & $\begin{array}{c}\text { Em geral } \\
\text { deve pre- } \\
\text { valecer a } \\
\text { posição } \\
\text { A }\end{array}$ & \begin{tabular}{|} 
As duas \\
posiçōes \\
têm igual \\
chance de \\
prevalecer
\end{tabular} & $\begin{array}{c}\text { Em geral } \\
\text { deve pre- } \\
\text { valecer a } \\
\text { posição } \\
\text { B } \\
\end{array}$ & \begin{tabular}{|c|} 
Deve \\
sempre \\
prevalecer \\
a posição \\
B \\
\end{tabular} & \begin{tabular}{|c|} 
Não \\
sabe/ \\
Sem \\
opinião
\end{tabular} & $\begin{array}{l}\text { Não } \\
\text { resp. }\end{array}$ \\
\hline \multirow[t]{2}{*}{ Trabalhista } & Freq & 68 & 82 & 176 & 280 & 59 & 35 & 41 \\
\hline & $\%$ & 9.2 & 11,1 & 23.8 & 37,8 & 8,0 & 4,7 & 5.5 \\
\hline \multirow[t]{2}{*}{ Comercial } & Freq & 125 & 243 & 185 & 78 & 20 & 42 & 48 \\
\hline & $\%$ & 16,9 & 32,8 & 25.0 & 10.5 & 2.7 & 5.7 & 6.5 \\
\hline \multirow{2}{*}{$\begin{array}{l}\text { Direitos do } \\
\text { Consumidor }\end{array}$} & Freq & 50 & 73 & 136 & 305 & 105 & 31 & 41 \\
\hline & $\%$ & 6.7 & 9,9 & 18,4 & 41,2 & 14,2 & 4,2 & 5,5 \\
\hline \multirow[t]{2}{*}{ Meio Ambiente } & Freq & 61 & 59 & 115 & 273 & 139 & 47 & 47 \\
\hline & $\%$ & 8,2 & 8,0 & 15,5 & 36,8 & 18,8 & 6,3 & 6,3 \\
\hline \multirow[t]{2}{*}{ Inquilinato } & Freq & 96 & 196 & 203 & 139 & 29 & 35 & 43 \\
\hline & $\%$ & 13,0 & 26.5 & 27.4 & 18.8 & 3,9 & 4,7 & 5.8 \\
\hline \multirow[t]{2}{*}{ Previdenciária } & Freq & 74 & 104 & 156 & 241 & 71 & 48 & 47 \\
\hline & $\%$ & 10,0 & 14,0 & 21,1 & 32,5 & 9,6 & 6,5 & 6,3 \\
\hline \multirow{2}{*}{$\begin{array}{l}\text { Mercado de } \\
\text { Crédito (e.g., juros) }\end{array}$} & Freq & 100 & 183 & 176 & 128 & 46 & 64 & 44 \\
\hline & $\%$ & 13,5 & 24,7 & 23,8 & 17,3 & 6,2 & 8,6 & 5,9 \\
\hline \multirow{2}{*}{$\begin{array}{l}\text { Regulação de } \\
\text { Serviços Públicos }\end{array}$} & Freq & 86 & 111 & 199 & 171 & 76 & 55 & 43 \\
\hline & $\%$ & 11,6 & 15,0 & 26.9 & 23.1 & 10.3 & 7.4 & 5,8 \\
\hline
\end{tabular}

Fonte: Pinheiro (2002). 


\section{O comportamento dos juízes}

A proposição de que os juízes tenderiam a decidir contra a lei e com isso promover a justiça social, através da distribuição de recursos para a parte mais fraca no processo, carece de uma fundamentação consistente.

Os juizes, assim como outros agentes econômicos, procuram maximizar sua utilidade. Diversas pesquisas já tentaram ligar as decisōes dos juízes ao favorecimento da classe ou grupo social a que estes pertencem. Desta forma, juízes que são donos de terras favoreceriam os donos de terras, juízes que caminham até o trabalho decidiriam em favor dos pedestres e assim por diante (Posner, 1995, p. 581). O ganho do juiz, nestes casos, seria ínfimo, e deveria ser sopesado em relação às possíveis penalidades de decidir contra a lei (por exemplo, a crítica de seus pares e do meio profissional, ou mesmo a reversão da decisão em grau de recurso). Essas tentativas de ligar o comportamento do juiz ao fato de este pertencer a uma classe ou grupo social, ou mesmo ao seu posicionamento ideológico, têm falhado consistentemente. ${ }^{5}$

A forma de seleção de juízes, via de regra por concurso público, acaba por privilegiar o conhecimento técnico (Zaffaroni, 1993, também Dallari, 2002, p. 2327). Nesse contexto, parece mais plausível o incentivo de decidir de acordo com a lei, defendido por Posner (1995) e por Glaeser, Scheinkman e Shleifer (2003, p. 203), do que a decisão de favorecer a parte mais fraca ao arrepio da lei. No caso brasileiro pesa ainda o critério de promoção dos juízes. Via de regra a promoção é feita em metade dos casos por antigüidade no posto e metade das vezes por mérito, sendo um dos quesitos do mérito a proporção de decisōes mantidas pelas instâncias superiores.

Ainda nesse sentido, Vianna (1997) verifica que os juízes em início de carreira tendem a decidir de forma mais técnica, e Sadek (2005) verifica uma tendência dos juízes em decidir segundo a lei, deixando em segundo plano considerações quanto aos impactos sociais e econômicos das decisōes.

\section{A validade das pesquisas de atitude}

A constatação de que não existe uma fundamentação microeconômica a respaldar a tese da incerteza jurisdicional não explica, entretanto, os resultados das pesquisas de Lamounier e Souza (2002) e de Pinheiro (2002).

\footnotetext{
5 Posner (1995, cap. 19, nota 19.7) cita como exemplos os estudos de POUND, Roscoe, The Economic Interpretation and the Law of Torts, Harvard Law Review 365 (1940); também ASHENFELTER, Orley; EISENBERG, Theodore; SCHWAB, Stewart J. Politics and the Judiciary: The Influence of Judicial Background on Case Outcomes, Journal of Legal Studies, 257 (1995). Veja ainda a respeito POSNER, Richard (1995), cap. 8.
} 
Esses estudos buscam suporte em medidas de atitude, para as quais é difícil garantir a isenção ideológica ou encontrar a exata correlação entre a atitude declinada pelo entrevistado e o seu comportamento. Nesses casos os resultados podem guardar pouca relação com a realidade.

Glaeser et al. (2000), debruçando-se sobre a relação entre medidas de confiança, ${ }^{6}$ verificam a pouca relação entre os valores apurados para o índice e os resultados de experimentos comportamentais feitos com incentivos financeiros (os chamados trust games). Embora aplicados à outra área, estes experimentos mostram a validade relativa das pesquisas de atitude, o que pode ser verificado também em testes semelhantes conduzidos no Brasil (Lazzarini et al. 2004). O que as pesquisas parecem mostrar é que os juízes desejam ter um papel socialmente relevante e engajado, o que não guarda necessariamente nenhuma relação com a forma como esses mesmos juízes efetivamente decidem.

Observando-se em especial os resultados apresentados por Pinheiro (2002), verifica-se que a disposição de menor adesão ao contrato aparece nas áreas que o legislador disciplinou de forma mais intensa, tolhendo a liberdade de contratação das partes - dessa forma, o juiz afastaria o contrato ao aplicar a lei nas situações em que a contratação fosse ilegal, e não por mera liberalidade.

A estrutura jurídica das normas de direitos sociais visa garantir que os hipossuficientes não sejam prejudicados em negociações contratuais. Por este motivo, a liberdade de negociação destes é limitada por normas cogentes, ${ }^{7}$ as quais não permitem a livre disposição de alguns direitos. Por exemplo, o trabalhador, mesmo que concorde em não receber suas férias, deverá recebê-las. $O$ empregador tem a obrigação legal de pagar pelas férias do empregado, não sendo válida qualquer cláusula contratual que disponha o contrário. Estas normas também são utilizadas pelo legislador para proteger o interesse público em todas as áreas do direito.

Deste modo, nas discussões contratuais que envolvem áreas mais reguladas, a variabilidade do resultado das decisōes judiciais entre aquelas em que o juiz observa os estritos termos do contrato e aquelas em que ele supostamente estaria fazendo justiça social poderá ser explicada pelo fato de estes contratos estarem contrariando a lei.

Nestas questões, o quadro de respostas dividido por áreas do direito (Tabela 3 retro) mostra uma variação do grau de adesão à estrita obediência do contrato. A apontada tendência à não-observância dos contratos é mais freqüente nas questões envolvendo đireitos sociais. Não casualmente, também esta é a área dos chamados "direitos novos". ${ }^{8}$ Verifica-se que nos direitos mais consolidados o percentual é menor (crédito e juros, comercial e inquilinato).

\footnotetext{
6 São os chamados índices de confiança - trust - disponíveis em pesquisas como o GSS (General Social Survey) e o WVS (World Values Survey).

- O termo normas cogentes define-se como normas jurídicas que não podem ser derrogadas pelas partes.

8 Direitos novos é o termo utilizado para definir direitos que foram consagrados pelo ordenamento jurídico após a Constituição de 1988.
} 


\section{O teste empírico}

O teste empírico realizado buscou encontrar evidências de um viés contra o credor. Diferentemente dos estudos anteriores, estas evidências foram procuradas não em pesquisas de opinião e de atitude, mas através do estudo de decisōes judiciais em diversas áreas.

Testou-se também a hipótese de que o julgador, quando afasta o contrato, o faz calcado na lei. Sendo a liberdade das partes de contratar limitada por normas que atendem ao interesse social ou à necessidade de proteger alguns valores democraticamente consagrados, quanto maior a quantidade dessas normas na área de interesse da contratação, maior a probabilidade de o contrato incorrer em ilegalidades, sendo necessário o seu afastamento por determinação legal e não por liberalidade do juiz.

A pesquisa empírica compreendeu a análise de acórdãos do Tribunal de Justiça de São Paulo e do Tribunal Regional do Trabalho ${ }^{10}$ e a entrevista com Desembargadores do Tribunal de Justiça de São Paulo.

Com o objetivo de delimitar o universo da pesquisa, restringiu-se o objeto de estudo às decisões judiciais de segunda instância da comarca de São Paulo, referentes às matérias de direito do consumidor, trabalhista, mercado de crédito, previdenciário, meio-ambiente, inquilinato, comercial e regulação de serviços públicos. ${ }^{11}$ Os acórdãos analisados traziam como cerne do litígio uma discussão contratual entre as partes.

A escolha baseou-se na competência recursal desses tribunais que julgam as açōes referentes às matérias acima descritas. A finalidade foi recolher as decisões que afastavam ou mantinham os contratos ou cláusulas contratuais em discussão. Os critérios de busca, bem como o intervalo de tempo e a forma de análise, estão detalhados no Anexo I, onde também pode ser encontrado o formulário utilizado.

O confronto entre as duas hipóteses da pesquisa se dá através da análise de regressão das 181 decisōes escolhidas entre os 1.019 acórdãos analisados. Em cada ocorrência foi determinado se houve a manutenção das cláusulas contratuais (atribuindo-se valor 1 à variável tipo dummy) ou se o contrato foi afastado (valor 0 ), sendo essa a variável a ser explicada nos testes.

\footnotetext{
9 O Tribunal de Justiça de São Paulo incorporou recentemente o Primeiro e Segundo Tribunal de Alçada do Estado de São Paulo em virtude da aprovaçāo da Emenda Constitucional $n^{2} 45$. Todavia, os bancos de dados destes tribunais ainda não foram unificados, o que justificou a pesquisa de alguns acórdāos nos bancos de dados respectivos.

10 Os acórdāos referentes à discussão contratual na matéria de Direito do Trabalho foram pesquisados no Tribunal Regional do Trabalho devido a sua competência material.

11 Estas áreas foram definidas pelo economista Armando Castelar Pinheiro no estudo "Judiciário, reforma e economia: uma visão dos magistrados" realizado em 2002. A metodologia de anáiise baseiase na utilizada por Ferrão et al. (2004).
} 
Cada uma dessas 181 decisões refere-se a uma das oito áreas utilizadas no estudo de Pinheiro (2002). Escores para a incidência de normas cogentes apuradas através de uma pesquisa entre desembargadores foram então associados a essas observações (a respeito da maior ou menor incidência de normas cogentes, veja a próxima seção). A hipótese principal da pesquisa é a de que, quanto maior a incidência de normas cogentes, menor a probabilidade da manutenção dos estritos termos do contrato.

Também se determinou se na discussão levada aos tribunais a manutenção das cláusulas contratuais era favorável à parte mais fraca ${ }^{12}$ na discussão (através de uma variável dummy com valor 1) ou favorável à parte mais forte (valor 0 ). Como em diversas das discussões não foi possível determinar a preponderância de uma das partes, o número de ocorrências nesse caso foi de 129 . Esta variável capta a hipótese de que o juiz faz justiça social à revelia da legislação aplicável. Por essa hipótese espera-se que quando o contrato for desfavorável à parte mais fraca se observará uma menor probabilidade da manutenção dos estritos termos do contrato.

Por fim, as avaliações técnicas, quanto ao fato de a preponderância de hipossuficiência determinar a maior incidência de normas cogentes em cada uma das áreas, foi transformada em dois novos indicadores, associados a cada uma das 181 ocorrências. O primeiro indicador mostra o porcentual de entrevistados que vislumbra a preponderância da hipossuficiência nas oito áreas e o segundo é uma variável dummy que assume o valor 1 quando esse porcentual for maior que $50 \%$ e 0 caso contrário. Esses indicadores tentam demonstrar a validade da hipótese alternativa, verificando se existe influência da hipossuficiência na probabilidade de manutenção do contrato além daquela determinada pela maior incidência de normas cogentes. Um coeficiente negativo aqui significaria que o juiz exorbita nas suas funções, considerando a afastabilidade do contrato além do previsto em lei.

\section{I A aferição da existência de normas cogentes}

A determinação de o quanto cada uma das áreas envolvidas na pesquisa está disciplinada por normas obrigatórias, que limitam a livre contratação entre as partes por escolha do legislador, não tem um indicador objetivo. Para determinar essa maior incidência de normas cogentes, o que vem a ser uma opinião em essência técnica, foi realizada uma pesquisa entre especialistas.

A simples ordenação das áreas ou o uso de uma classificação usando escalas do tipo Likert tornaria difícil a análise posterior, essencialmente quantitativa. A transformação de escalas com itens do tipo grande incidência de normas cogentes e

12 O conceito de parte mais fraca é mais amplo que o de parte hipossuficiente, e refere-se à visível desvantagem na relação econômica e, por vezes, processual. 
pouca incidência de normas cogentes em valores através do cálculo de médias é um mecanismo bastante questionável. Foi adotado como estratégia solicitar a aferição dos especialistas, desde o início, em termos quantitativos, de forma a permitir o cálculo de médias e a análise por modelos de regressão.

Assim, a apuração do percentual de normas cogentes em cada tipo de ação foi feita através de formulários de graphic rating scales, ${ }^{13}$ aplicados aos juízes solicitando uma avaliação técnica quanto a este quesito. Optou-se, após testes preliminares, pela escala gráfica, verificando-se o número de itens pertinentes e a necessidade de um número par ou ímpar de valores. O resultado desta avaliação técnica vai atribuir um score para cada tipo de área, permitindo uma ordem de classificação no quesito de maior ou menor incidência de normas cogentes. A média das avaliaçōes quanto à incidência de normas cogentes, em uma escala contínua de 1 a 7 , pode ser verificada na Tabela 4 com os respectivos desvios-padrão.

A existência do viés pró-devedor poderia se manifestar já nessa avaliação, que, a priori, é estritamente técnica. Juízes com maior tendência a subverter o contrato poderiam vislumbrar uma maior incidência de normas cogentes nas áreas onde o afastamento do contrato é mais provável.

Para afastar essa hipótese, foram calculadas as médias para os subgrupos apresentados na Tabela 4, comparando as avaliaçōes dos entrevistados que se definiram como de esquerda ou centro-esquerda com a avaliação dos que se definiram como sendo de direita ou centro-direita.

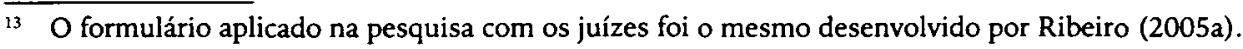


Tabela 4 Regressões OLS para determinantes da avaliação de normas cogentes. ${ }^{*}$

\begin{tabular}{|c|c|c|c|c|c|c|}
\hline & $2^{\prime}$ & $4^{\prime}$ & $6^{\prime}$ & $8^{\prime}$ & $9^{\prime}$ & $10^{1}$ \\
\hline $\begin{array}{l}\text { Hipossuficiência ff. avaliaçäo pes- } \\
\text { soal-dummy }\end{array}$ & $\begin{array}{c}1.3083 \\
(0.2570)\end{array}$ & & & & $\begin{array}{c}0,6096 \\
(0,4077)\end{array}$ & $\begin{array}{l}0.6566 \\
(0.3702)\end{array}$ \\
\hline $\begin{array}{l}\text { Hipossuficiência cf. média das ava- } \\
\text { liaçōes }\end{array}$ & & $\begin{array}{c}0,0233 \\
(0,0040)\end{array}$ & & & & \\
\hline $\begin{array}{l}\text { Hipossuficiência cf. média das ava- } \\
\text { liaçōes - dumimy }\end{array}$ & & & $\begin{array}{l}1.6036 \\
(0.2223)\end{array}$ & & & \\
\hline $\begin{array}{l}\text { Interesse público } f \text {. avaliação pes- } \\
\text { soa! - dummy }\end{array}$ & & & & $\begin{array}{l}-1,1668 \\
(0.2792)\end{array}$ & $\begin{array}{r}-0,6726 \\
(0,4160)\end{array}$ & $\begin{array}{l}-0,5882 \\
(0,3742)\end{array}$ \\
\hline $\begin{array}{l}\text { Definiçāo política como esquerda } \\
\text { ou centro-esquerda }\end{array}$ & $\begin{array}{c}0.1135 \\
(0.39 ! 2)\end{array}$ & $\begin{array}{c}0.2788 \\
(0.3762)\end{array}$ & $\begin{array}{r}0.2793 \\
(0,3740)\end{array}$ & $\begin{array}{c}0,4060 \\
(0,37 \mid 8)\end{array}$ & & \\
\hline $\begin{array}{l}\text { Definiçāo politica como direita ou } \\
\text { centro-direita }\end{array}$ & $\begin{array}{l}-0,3372 \\
(0,3965)\end{array}$ & $\begin{array}{r}-0,3156 \\
(0,3832)\end{array}$ & $\begin{array}{l}-0.3177 \\
(0.3783)\end{array}$ & $\begin{array}{c}0,0376 \\
(0,3453)\end{array}$ & & \\
\hline Idade & $\begin{array}{c}0,0184 \\
(0,0287)\end{array}$ & $\begin{array}{l}0,0107 \\
(0,0278)\end{array}$ & $\begin{array}{c}0.0105 \\
(0.0274)\end{array}$ & & & \\
\hline Tempo na profissão & & & & $\begin{array}{l}0.0272 \\
(0.0227)\end{array}$ & & \\
\hline Constante & $\begin{array}{l}3.3187 \\
(1.5031)\end{array}$ & $\begin{array}{r}3.4783 \\
(1.4587) \\
\end{array}$ & $\begin{array}{r}3.5950 \\
(1.4362) \\
\end{array}$ & $\begin{array}{r}4.48 ! 2 \\
(0.5455)\end{array}$ & $\begin{array}{c}4.4621 \\
(0,4441)\end{array}$ & $\begin{array}{c}4,7424 \\
(0,3352)\end{array}$ \\
\hline № de Observaçōes & 151 & 151 & 151 & 151 & 207 & 239 \\
\hline Estatística F & 3.94 & 5,39 & 6.34 & 4,27 & 5.96 & 8.82 \\
\hline$R^{i}$ & 0.07 & 0,10 & 0.12 & 0.08 & 0,07 & 0.06 \\
\hline
\end{tabular}

* Erro padrāo robusto de Huber/White.

Seria possível também que magistrados mais velhos tivessem uma postura mais conservadora e menos intervencionista (Vianna et al., 1997, p. 218-226), levando essa diferença de postura à identificação de uma maior ou menor incidência de normas cogentes. Para testar essa hipótese foram calculadas as médias para o $1^{\circ}$ quartil e o $4^{\circ}$ quartil da amostra ordenada por idade, apresentadas na Tabela 5. Por fim, um menor tempo de experiência poderia levar a erros de avaliação, e para dirimir este ponto foram calculadas as médias também do $1^{\circ}$ e $4^{\circ}$ quartil, mas com relação ao tempo de serviço. 
Tabela 5 Diferenças de médias.

\begin{tabular}{|c|c|c|c|c|c|c|c|c|}
\hline & Trab. & Comerc. & Consum. & Ambient. & Inquilin. & Previd. & Crédito & Regul \\
\hline Tempo de serviço $I^{2}$ quartil & 5,93 & 1,32 & 5.21 & 6,50 & 2,75 & 5,71 & 1,93 & 5,14 \\
\hline Tempo de serviçっ $4^{\circ}$ quartil & 5,79 & 2,07 & 5.57 & 6,50 & 3,21 & 5,61 & 2,25 & 5.32 \\
\hline Idade $I^{\circ}$ quartil & 5.96 & 1,71 & 5.29 & 6.29 & 2,89 & 6,07 & 2,11 & 5.04 \\
\hline Idade $4^{\circ}$ quartil & 5.89 & 1.82 & 5.50 & 6,50 & 2.86 & 5,38 & 2.07 & 5,25 \\
\hline Esquerda ou centro-esquerda & 6,25 & 2,08 & 5.79 & 6,67 & 3,79 & 6.29 & 2,29 & 5,67 \\
\hline Direita ou centro-direita & 6.13 & 1,16 & 5,28 & 6,81 & 2,50 & 5,96 & 1,97 & 4,72 \\
\hline Média Total & 5,94 & 1,68 & 5,43 & 6,53 & 2,94 & 6,03 & 2,32 & 5.23 \\
\hline Desvio-padrāo & 0,76 & 0,88 & 0,59 & 0,76 & 0,80 & 0,76 & 0,84 & 0.95 \\
\hline
\end{tabular}

Todas as médias são próximas entre si e da média geral. Considerando-se o número de entrevistas, verifica-se que mesmo nos piores casos âs diferenças não são significativas.

Poderia-se alegar que o número de entrevistas não permitiria identificar o possivel viés. A hipótese de influências de posição ideológica ou de atitudes mais ou menos conservadoras foi então testada através de análises de regressão. Como os respondentes apresentaram sua avaliação para as oito áreas, têm-se assim 240 observaçōes que foram testadas nas regressōes apresentadas na Tabela 4. Foram também incluídas como variáveis explicativas as avaliaçōes quanto a preponderância de razōes de ordem pública ou da existência de parte hipossuficiente como determinantes da incidência de normas cogentes em cada área do direito.

Estas avaliações dividem-se entre as pessoais, que poderiam refletir um componente idiossincrático, e as médias do grupo entrevistado. A variância das avaliações em cada uma das oito áreas também pode não ser igual, o que implicaria um problema de heterocedasticidade. Foram apresentadas especificaçōes alternativas, utilizando a especificação dos desvios-padrão robusta de White (1980).

A primeira observação é a de que os $\mathrm{R}^{2}$ de todas as regressōes ficam entre 0,06 e 0,12 , ou seja, todas as variáveis elencadas explicam muito pouco a maior incidência de norrnas cogentes, sendo sua determinação exógena (possivelmente atrelada a critérios do processo legislativo ou outras fontes). Também, em todas as especificaçōes, as variáveis de posiçāo ideológica, idade e tempo de exercício da profissão não são significativas.

A verificação da existência de um critério de hipossuficiência aumenta de forma significativa a incidência de normas cogentes na área em questão, e a existência de um interesse público a ser tutelado normalmente reduz o nível de intervenção. Também se verifica que as avaliaçōes pessoais, quanto à preponderância da hipossuficiência (equações 1, 2, 9 e 10), têm um p-valor em gera! menor e apresentam coeficientes menores que os das avaliações correspondentes fundadas na média das avaliaçōes (equações 5 e 6 ). 
A diferença quanto aos coeficientes fundados em avaliação pessoal e as médias indicam que não existe um componente idiossincrático nos escores apresentados pelos desembargadores, reforçando a idéia de um indicador estritamente técnico.

A significância dos princípios de ordem pública e proteção ao hipossuficiente, na forma testada, indicam a determinação de maiores níveis de ingerência por parte do legislador. A menor liberdade das partes para contratar não decorre de nenhuma forma do Judiciário, que vislumbra apenas as limitaçōes escolhidas pelo legislador. ${ }^{14} \mathrm{Tal}$ conclusão, entretanto, não significa que o Judiciário aplique estritamente a lei e deixe de fazer justiça social com as próprias mãos, sendo necessário o teste empírico da próxima seção para verificar o estrito cumprimento da lei.

Por outro lado, a menor incidência de normas cogentes, quando verificado o interesse público a fundamentar a restrição do direito de contratar, é a expressão de um Estado que incorporou a idéia da intervenção mínima. O resultado é que, nas áreas em que não se observa a hipossuficiência de forma tão marcante (mercado de crédito, comercial e inquilinato), ${ }^{15}$ o escore atribuído na avaliação técnica pelos desembargadores é muito menor.

\section{Os resultados}

O modelo de regressão utilizado envolve, conforme se verifica, a determinação da influência das variáveis explicativas enumeradas sobre a escolha entre afastar ou não o contrato. Isto significa que, dado o caráter dicotômico da variável que se pretende explicar, que assume apenas o valor de 0 (zero) ou 1 (um), o modelo de regressão apresenta o quanto cada aumento nas variáveis explicativas influi na probabilidade do contrato ser mantido. Os testes do artigo foram feitos usando o chamado modelo de probabilidade probit, que utiliza uma função de probabilidade normal acumulada, na forma a seguir:

$$
P(y=1 \mid x)=F\left(\beta_{0}+x \beta\right)
$$

\footnotetext{
14 A verificaçāo de que a proteção ao hipossuficiente é política emanada do legislador poderia levar à argumentação por parte de alguns de que, então, a insegurança jurídica viria do Legislativo, e não do Judiciário. Dois problemas aparecem nesse argumento: o primeiro é o de que, se foi estabelecida em lei a proteção, nāo existe incerteza e o contrato somente é afastado quando ilegal. O segundo é a presunção implícita na argumentação de que a legislação é fruto das irracionalidades do Legislativo e não livremente determinada no jogo das pressóes políticas, sendo a manifestação da medida de bemestar social (Sen, 2002).

15 A localização do direito das locações como uma das áreas de menor incidência de normas cogentes é significativo da reduçāo da ingerência do Estado nos negócios entre particulares. Típico exemplo de intervenções desastrosas ao equilíbrio de mercado feitas pelo legislador, no Brasil houve uma evoluçāo da vigência da Lei $6.649 / 79$, que desorganizou por completo o mercado de imóveis de aluguel, até sua substituição pela Lei 8.245 , de 18 de outubro de 1991 .
} 
onde $x \beta$ é o vetor de variáveis explicativas que inclui o índice de normas cogentes, as variáveis dummy para identificar a existência de contrato favorável à parte mais fraca ou não, a existência de parte hipossuficiente ou ainda de interesse público, e, por fim, o porcentual de entrevistados que vislumbrou a existência de hipossuficiência na matéria discutida.

Esta função dá a probabilidade de um parâmetro $z$ determinado de forma linear pelos regressores, ou seja, poderíamos de forma abreviada usar a notação $P_{i}=F\left(z_{i}\right)$. A função normal acumulada padronizada é escrita como:

$$
P_{i}=F\left(z_{i}\right)=\frac{1}{\sqrt{2 \pi}} \int_{-\infty}^{z_{i}} e^{-s^{2} / 2}
$$

onde s é uma variável aleatória com distribuição normal, média zero e variância igual a um. A curva de probabilidade resultante terá uma inclinação menor nos valores extremos e uma inclinação maior nos valores intermediários, e a estimação dos parâmetros se faz pelo critério de máxima verossimilhança.

O problema é a interpretação dos coeficientes resultantes, que determinam não a influência sobre a probabilidade diretamente, mas a influência linear dos regressores sobre o parâmetro $Z$ da função de probabilidade acumulada. Adicionalmente, a variação da probabilidade não é linear, sendo maior nas faixas próximas a 0,5 e menor nas extremidades. Por conta disso, nos resultados apresentados nas Tabelas 6 e 7, ${ }^{16}$ os valores apresentados não são os coeficientes, mas sim a resposta da probabilidade para uma variação infinitesimal de cada regressor nas proximidades da probabilidade média (ou seja, a derivada no ponto de probabilidade 0,5 ).

Por fim, tem-se o problema da heterocedasticidade também nessas regressões, dada a mesma possibilidade de variâncias diferentes em cada uma das oito áreas pesquisadas. De fato, as especificações usando a matriz de Huber/White apresentaram valores de desvio-padrão menores, assim as tabelas reportam apenas as especificaçōes com o erro robusto a heterocedasticidade.

A hipótese da incerteza jurisdicional foi testada isoladamente nas equaçōes 1 e 2 da Tabela 6 . A primeira equação testa a maior probabilidade de manutenção do contrato quando este favorece a parte mais forte, apresentando resultado não significativo para toda a amostra (equação 1). O resultado da equação 2 é mais sonoro - foram testadas nessa especificação apenas as açōes judiciais das áreas de direito comercial e crédito (justamente as apontadas como problemáticas por Arida et al., 2005, e por Pinheiro, 2002), resultando que, de forma bastante significativa, a parte mais forte tem $39 \%$ mais de chance de ter o contrato que lhe favorece mantido do que a parte mais fraca na mesma situação.

Os resultados das equações 3 a 7 da Tabela 6 apresentam valores significantes para a influência negativa do aumento de normas cogentes sobre a probabilidade

16 As Tabelas 6 e 7 foram produzidas com o pacote estatístico Stata/SE 8.0 da Stata Corporation. 
de observância dos contratos. Estes porcentuais são aumentados de um mínimo de 19\% (conforme a equação 4) até um máximo de 56\% (equação 5) para um aumento de 1 (um) no índice de avaliação quanto à quantidade de normas cogentes.

A hipótese do favorecimento da parte mais fraca não é significante, portanto, em nenhuma das especificações, quer na situação em que o contrato seria desfavorável à parte mais fraca (equações 1 a 4), quer na hipótese de exorbitância do juiz, favorecendo a parte hipossuficiente além da previsão legal (equações 5 a 7).

Tabela 6 Alteração na probabilidade de seguir o contrato.

\begin{tabular}{|c|c|c|c|c|c|c|c|}
\hline & 1 & 2 & 3 & 4 & 5 & 6 & 7 \\
\hline $\begin{array}{l}\text { Maior incidência de } \\
\text { normas cogentes }\end{array}$ & & & $\begin{array}{c}-0,2228 * * * \\
(0.0264)\end{array}$ & $\begin{array}{c}-0.1899 * * * \\
(0.0293)\end{array}$ & $\begin{array}{c}-0.5586 * * * \\
(0.0716)\end{array}$ & $\begin{array}{c}-0,5042^{* * *} \\
(0,0906)\end{array}$ & $\begin{array}{c}-0.5195 * * * \\
(0.0903)\end{array}$ \\
\hline $\begin{array}{l}\text { Parte mais forte fav. } \\
\text { pelo contrato }\end{array}$ & $\begin{array}{l}-0.0842 \\
(0.1102)\end{array}$ & $\begin{array}{l}0.3885 * * \\
(0,1941)\end{array}$ & & $\begin{array}{l}-0.0682 \\
(0.1425)\end{array}$ & & $\begin{array}{l}-0.1688 \\
(0,3892)\end{array}$ & $\begin{array}{l}-0.1950 \\
(0.3937)\end{array}$ \\
\hline $\begin{array}{l}\text { Influência da hipossu- } \\
\text { ficiência }\end{array}$ & & & & & $\begin{array}{l}-0.0002 \\
(0.0043) \\
\end{array}$ & $\begin{array}{l}-0.0007 \\
(0.0052) \\
\end{array}$ & \\
\hline $\begin{array}{l}\text { Infuência da hipos. } \\
\text { - dummy }\end{array}$ & & & & & & & $\begin{array}{c}0.0589 \\
(0.3227)\end{array}$ \\
\hline Constante & & & & & $\begin{array}{c}2.3775 * * \\
(0,3148)\end{array}$ & $\begin{array}{c}2.1770 * * \\
(0.5450)\end{array}$ & $\begin{array}{c}2.2216^{* * *} \\
(0.5581)\end{array}$ \\
\hline $\begin{array}{l}\text { Número de Obser- } \\
\text { vaçōes }\end{array}$ & 129 & 32 & 181 & 129 & 181 & 129 & 129 \\
\hline $\begin{array}{l}\text { Log da Verossimi- } \\
\text { thança }\end{array}$ & $-8,4,8465$ & $-8,9789$ & -83.4932 & $-61,0164$ & -83.4926 & $-61,0053$ & -60.998 \\
\hline Pseudo $R^{i}$ & 0.00 & 0.26 & 0.33 & 0.28 & 0.33 & 0.28 & 0.28 \\
\hline
\end{tabular}

1 - Os números mostram a alteração na probabilidade de seguir o contrato $(\mathrm{dF} / \mathrm{dx})$ decorrente de uma alieração infinitesimal nas variáveis independentes contínlias ou de uma alteração discreta nas variáveis dummy quando esta probabilidade está próxima da média (50\%). 2 - Erro padrāo robusto de Huber/White. ${ }^{* *}$ significante a $1 \%,{ }^{* *}$ significante a $5 \%,{ }^{*}$ significante a $10 \%$.

O que os resultados mostram é que o juiz afasta o contrato porque este é ilegal, e que a chance de descumprimento da lei é maior quando o número de normas limitando a livre contratação é maior. Não existe favorecimento voluntário à parte em desvantagem na relação, assim como o juiz não exorbita em suas atribuições, protegendo estas partes além do disciplinado em lei.

\section{I Prevalência da parte mais forte}

Quando se testa a interação entre a edição de normas cogentes e a existência de cláusulas contratuais favorecendo a parte mais forte, a conclusão também é 
a inversa à hipótese da Arida et al. (2005), como se verifica nas equações 8 e 9 (Tabela 7). Constata-se de forma significante que uma parte mais forte que tenha uma cláusula contratual a seu favor tem $45 \%$ a mais de chance de ver o contrato mantido, se comparada a uma parte mais fraca que também tenha uma cláusula contratual a seu favor. Essa parte mais forte terá uma chance maior de ver o contrato que lhe é favorável afastado apenas quando existirem mais normas cogentes (ou seja, em áreas como a trabalhista, ambiental e previdenciária), entretanto essa redução da probabilidade de preservação do contrato será bem mais modesta (em torno de 15\%). ${ }^{17}$ As especificações incluindo a interação entre o índice de normas cogentes e a existência de uma parte mais forte com o índice de normas cogentes em separado permitem encontrar o efeito líquido da limitaçăo à contratação sobre o resultado das ações em que o contrato favorece o mais forte.

Tabela 7 Alteração na probabilidade de seguir o contrato $(d F / d x)^{1}$ - Interação entre va-

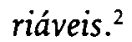

\begin{tabular}{|c|c|c|c|c|c|c|}
\hline & 8 & 9 & 10 & 11 & 12 & 13 \\
\hline $\begin{array}{l}\text { Maior incidência de normas } \\
\text { cogentes }\end{array}$ & $\begin{array}{l}-0,0764 \\
(0,0528)\end{array}$ & $\begin{array}{l}-0,0764 \\
(0,0508)\end{array}$ & $\begin{array}{c}-0,1933 * * * \\
(0,0367)\end{array}$ & $\begin{array}{c}-0,1933 * * * \\
(0,0361)\end{array}$ & $\begin{array}{c}-0,1889 * * * \\
(0,03 \mid 1)\end{array}$ & $\begin{array}{c}-0,1889 * * * \\
(0,0295)\end{array}$ \\
\hline $\begin{array}{l}\text { Parte mais forte favorecida } \\
\text { pelo contrato }\end{array}$ & $\begin{array}{l}0,4541 * * \\
(0.1247)\end{array}$ & $\begin{array}{l}0.4541 * * \\
(0,1166) \\
\end{array}$ & $\begin{array}{l}-0,0734 \\
(0,1252)\end{array}$ & $\begin{array}{l}-0.0734 \\
(0,1524) \\
\end{array}$ & $\begin{array}{r}-0,0743 \\
(0,1248) \\
\end{array}$ & $\begin{array}{c}-0,0743 \\
(0,15189)\end{array}$ \\
\hline $\begin{array}{l}\text { Interação normas cogentes } \\
\text { com parte mais forte }\end{array}$ & $\begin{array}{c}-0,1587^{* *} \\
(0,0654) \\
\end{array}$ & $\begin{array}{c}-0.1587^{* * *} \\
(0.0613)\end{array}$ & & & & \\
\hline $\begin{array}{l}\text { Interaçāo normas cogentes } \\
\text { com hipossuficiência }\end{array}$ & & & $\begin{array}{l}0,0061 \\
(0,0358)\end{array}$ & $\begin{array}{c}0.0061 \\
(0.0360)\end{array}$ & & \\
\hline $\begin{array}{l}\text { Interaçäo normas cogentes } \\
\text { com interesse público }\end{array}$ & & & & & $\begin{array}{l}-0,0044 \\
(0,0203)\end{array}$ & $\begin{array}{l}-0,0044 \\
(0,02 ! 3)\end{array}$ \\
\hline
\end{tabular}

\begin{tabular}{lcccccc}
\hline Número de observações & 128 & 128 & 129 & 129 & 129 & 129 \\
\hline Log da Verossimihança & -57.8860 & -57.8850 & -61.0019 & -61.0019 & -60.9930 & -60.9930 \\
\hline Pseudo $R^{2}$ & 0.31 & 0.31 & 0.28 & 0.28 & 0.28 & 0.28 \\
\hline
\end{tabular}

1 - Os números mostram a alteração na probabilidade de seguir o contrato $(\mathrm{dF} / \mathrm{dx})$ decorrente de uma alteração infinitesimal nas variáveis independentes contínuas ou de uma alreração discreta nas variáveis dummy quando esta probabilidade está próxima da média (50\%). 2 - Erro padrão robusto de Huber/White. ${ }^{* * *}$ significante a $1 \%,{ }^{* *}$ significante a $5 \%,{ }^{*}$ significante a $10 \%$.

Verifica-se, além disso, que não existe significância da interação de normas cogentes com a existência de interesse público ou de hipossuficiência, resultando que o juiz se atém aos estritos termos da lei quando observadas essas duas condiçōes, e o contrato é afastado apenas quando eivado de ilegalidade.

${ }_{17}$ Os dois valores ieferem-se à derivada no ponto médio, entretanto, no caso do índice de normas cogentes, referem-se a um aumento de 1 ponto no indicador, enquanto que para a existência de parte mais fraca trata-se de uma dummy. 
O teste com as interações mostra que nas áreas apontadas como problemáticas por Pinheiro $(2003,2001)$ e Arida et al. (2005), nomeadamente as de crédito e juros bancários e relações comerciais, há um crescimento da probabilidade de manutenção do contrato de $39 \%$ para $45 \%$, quando são isolados os efeitos da edição de normas cogentes. O fenômeno que aqui ocorre pode ser descrito como uma decisão do legislador pela menor intervenção na vontade das partes quando apenas o interesse público está em jogo, decisão esta que, ao ser mantida pelo juiz, deixa as partes entregues à própria sorte, com a esperada prevalência do mais forte.

O favorecimento dos economicamente privilegiados não se dá através da intervenção direta, mas sim de uma neutralidade que ignora as maiores chances de defesa que o litigante organizacional ${ }^{18}$ naturalmente tem a seu favor.

Verifica-se ainda que a grande vantagem da parte mais forte é apenas levemente mitigada, com uma redução equivalente a apenas um terço de sua vantagem inicial, quando a legislação (e não o juiz) intervém em favor do hipossuficiente.

\section{Conclusão}

O resultado da análise do material empírico coletado demonstra a validade da interpretação das decisões, e contabiliza de forma bastante objetiva o afastamento ou não da cláusula social. Também bastante objetiva foi a identificação de uma parte mais forte ou mais fraca sendo favorecida pelo contrato, embora, em um primeiro momento, a amostra tenha se reduzido nessa análise (de 181 observações para 129).

O levantamento de um critério técnico quanto a maior ou menor incidência de normas cogentes poderia suscitar dúvidas quanto a sua isenção e objetividade. Na seção 5.1, entretanto, fica demonstrada cabalmente a isenção e objetividade da medida técnica.

A pesquisa baseada em opinião poderia deixar alguma dúvida quanto à precisão da medida, frente a um dado tão objetivo como o que tenta sustentar a hipótese da incerteza jurisdicional. O resultado final, entretanto, que confirmou a hipótese principal e não encontrou indícios de significância da hipótese alternativa, mostra que mesmo a possível existência de erro de medida, ao prejudicar a hipótese principal, não impediu sua confirmaçāo. Podem-se resumir os resultados discutidos na análise empírica, quanto ao levantamento do critério técnico, através do Quadro 1.

18 O litigante organizacional pode ser definido como aquele que, dado o porte de suas atividades, recorre com freqüência à justiça. Este litigante habitual conta com um corpo de advogados próprios, tem ganhos de escala na condução das açōes judiciais, fôlego financeiro para esperar o seu desfecho e consegue testar diversas teses e estratégias de defesa, entre outras vantagens (Galanter, 1974, Cappelletti; Garth, 1978). 
Quadro 1 Resumo das conclusões da pesquisa técnica.

\begin{tabular}{|l|c|}
\hline & $\begin{array}{c}\text { Quantidade de normas } \\
\text { cogentes editadas pelo } \\
\text { legislador, na avaliação do } \\
\text { magistrado }\end{array}$ \\
\hline Quantidade de normas cogentes quando existe hipossuficiência & Aumenta \\
\hline $\begin{array}{l}\text { Quantidade de normas cogentes quando o interesse público é de outra } \\
\text { natureza }\end{array}$ & Diminui \\
\hline $\begin{array}{l}\text { Posicionamento ideológico do magistrado definido como de esquerda } \\
\text { ou centro-esquerda }\end{array}$ & Não se altera \\
\hline $\begin{array}{l}\text { Posicionamento ideológico do magistrado definido como de direita ou } \\
\text { centro-direita }\end{array}$ & Não se altera \\
\hline Maior experiência ou idade do magistrado & Não se altera \\
\hline
\end{tabular}

O confronto das duas hipóteses, detalhado no restante da item 6 , fundamenta de forma significativa e consistente a hipótese principal, ao afastar a hipótese de Pinheiro $(2003,2001)$ e de Arida et al. (2004). Pode-se observar no Quadro 2 um resumo das conclusões do teste empírico.

Quadro 2 Resumo da análise dos acórdãos.

\begin{tabular}{|l|c|c|}
\hline & \multicolumn{1}{|c|}{$\begin{array}{c}\text { Menor incidência de } \\
\text { normas cogentes }\end{array}$} & $\begin{array}{c}\text { Maior incidência de } \\
\text { normas cogentes }\end{array}$ \\
\hline Áreas & $\begin{array}{c}\text { Comercial, crédito e juros, } \\
\text { inquilinato }\end{array}$ & $\begin{array}{c}\text { Trabalhista, consumidor, } \\
\text { meio ambiente e, em menor } \\
\text { escala, regulação de serviços } \\
\text { públicos e previdenciário }\end{array}$ \\
\hline $\begin{array}{l}\text { Possibilidade de manutenção do } \\
\text { contrato quando favorece a parte } \\
\text { mais forte }\end{array}$ & $\begin{array}{c}45 \% \text { maior do que quando } \\
\text { o contrato favorece a parte } \\
\text { mais fraca }\end{array}$ & $\begin{array}{c}\text { A vantagem de 45\% é em } \\
\text { parte mitigada por uma } \\
\text { redução de 15\% da chance } \\
\text { de manutenção do contrato }\end{array}$ \\
\hline $\begin{array}{l}\text { Possibilidade de o juiz favorecer a } \\
\text { parte hipossuficiente além do esta- } \\
\text { belecido em lei }\end{array}$ & Nenhuma & Nenhuma \\
\hline $\begin{array}{l}\text { Possibilidade de o juiz afastar o con- } \\
\text { trato além do estabelecido em lei } \\
\text { em função de interesse público }\end{array}$ & Nenhuma & Nenhuma \\
\hline
\end{tabular}

O contrato é relativizado apenas quando eivado de ilegalidade, não se identificando nenhuma voluntariedade do Judiciário no sentido de defender as partes hipossuficientes, além do estabelecido em lei. Mais do que isso, nas áreas que seriam mais sensiveis à existência de um viés intervencionista da justiça, a do 
crédito e juros, comercial e do inquilinato, vigora a livre contratação e a pouca interferência tanto do legislador quanto dos magistrados. Os riscos de afastamento do contrato estariam nas áreas mais reguladas, como por exemplo nas questões trabalhistas, de seguridade social e ambiental.

Nas entrevistas com os desembargadores e na análise qualitativa dos acórdãos, foi bastante fácil perceber a isenção dos magistrados que evitam tolher a liberdade dos contratantes além do disposto no ordenamento jurídico, resultado que, de resto, não surpreende nem aos advogados nem aos membros do Judiciário. A forma como se elabora o conceito de incerteza jurisdicional ignora os incentivos que influem no comportamento dos juízes e das partes e pode levar a reformas institucionais que não !evarão aos resultados esperados. Nas palavras de Douglass North, "an immense amount of economic change that reflected a significant gap between intentions and outcomes as a result of 'faulty' beliefs. The fault may lie in not understanding the situation correctly but also in the revised institutional structure not altering behavior in intended ways". ${ }^{19}$

\section{Bibliografia}

AMARAL, P.; QUINTIN, E. Making finance matter. Working Paper, Federal Reserve Bank of Dallas, 2004. Disponível em: <http://www.ssc.uwo.ca/economics/newsletter/misc/2004/AmaralDec9.pdf>. Acessado em: 2 junho 2005.

ANTUNES, António; CAVALCANTI, Tiago; VILLAMIL, Anne. Intermediation costs, investor protection and economic development. Mimeo. II ENCONTRO CAEN/UFCEPGE/FGV DE POLÍTICAS PÚBLICAS E CRESCIMENTO ECONÔMICO, Fortaleza, CAEN/EPGE, 30 e 31 de maio de 2005.

ARIDA, Pérsio; BACHA, Edmar; RESENDE, André Lara. Credit, interest, and jurisdictional uncertainty: conjectures on the case of Brazil. Rio de Janeiro: IEPE/CdG. Texto para Discussão n 2, 2003, publicado em GIAVAZZI. F.; GOLDFAJN, I.; HERRERA, S. (Org.). Inflation targeting, debt, and the Brazilian experience, 1999 to 2003. Cambridge, MA: MIT Press, May 2005.

BARRO, Robert. Economic growth in a cross section of countries. The Quarterly Journal of Economics, [S.1.], v. 106, $\mathrm{n}^{\mathrm{0}}$ 2, May 1991, p. 407-443.

BELAISCH, Agnês. Do Brazilian banks compete? IMF working paper 03/113, May 2003. Disponível em: <www.febraban.org.br/Arquivo/Destaques/Paper_Belaisch_Concorr\%EAncia.pdf>. Acesso em:12 set. 2005.

BUSCAGLIA, Eduardo; DAKOLIAS, Maria. An analysis of the causes of corruption in the Judiciary. Law and Policy in International Business, Georgetown University Law Center, v. 30, p. 95-107, 1999.

19 Understanding the Process of Economic Change, 2005, p. 77. 
CAPPELLETTI, Mauro; GARTH, Bryant. Access to justice. Milan: Dott. A. Giuffrè Editore, 1978. v. 1.

COASE, Ronald Harry. The nature of the firm. The firm, the market, and the law. The University of Chicago Press, 1995.

DALLARI, Dalmo. O poder dos juízes. São Paulo: Saraiva, 2002.

FERRÃO, Brisa L. de M. A influência do comportamento dos magistrados brasileiros no problema da incerteza jurisdicional: um teste empírico. Monografia de final de curso defendida na Faculdade de Direito da USP em 2005.

FERRÃO, Brisa L. de $M$ et al. $O$ judiciário e as políticas públicas de saúde no Brasil: o caso AIDS. Prêmio IPEA 40 Anos. IPEA-CAIXA, 2004, Monografia premiada, p. 387-432, Brasília: Ipea, 2005.

FACHADA, Pedro; FIGUEIREDO, Luiz Fernando; LUNDBERG, Eduardo. Sistema judicial e mercado de crédito no Brasil. Nota Técnica do Banco Central do Brasil $\mathrm{n}^{\circ}$ 35, Março de 2003. Disponível em: <http://www.bcb.gov.br/pec/NotasTecnicas/Port/2003nt35sistemajudiciaimercadocredbrasilp.pdf $>$. Acesso em: 9 maio 2004.

FUNDAÇÃO GETULIO VARGAS. A Reforma do Poder Judiciário no Estado do Rio de Janeiro. Rio de Janeiro: FGV, 2005.

GALANTER, Marc. Why the Haves come out ahead: speculations on the limits of legal change. Law and Society Review, Fall 1974, p. 95-160.

GLAESER, E. L.; LAIBSON, D. I.; SCHEINKMAN, J. A.; SOUTTER, C. L. Measuring trust. The Quarterly Journal of Economics, v. 115(3), p. 811-846, 2000.

GLAESER, Edward; SCHEINKMAN, José; SHLEIFER, Andrei. The injustice of inequality. Journal of Monetary Economics, 50, 2003, p. 199-222.

GONÇALVES, Fernando M.; HOLLAND, Marcio; SPACOV, Andrei D. Can jurisdictional uncertainty and capital controls explain the high level of real interest rates in Brazil? Evidence from panel data. Mimeos fornecidos pelos autores, junho 2005.

KNACK, S.; KEEFER, P. Institutions and economic performance: cross-country tests using alternative institutional measures. Economics and Politics, [S.1.], 7, 1995, p. 207-227.

LAEVEN, Luc; MAJNONI, Giovanni. Does judicial efficiency lower the cost of credit? World Bank Policy Research Working Paper 3159, 2003.

LAMOUNIER, B; SOUZA, A. As elites brasileiras e o desenvolvimento nacional: fatores de consenso e dissenso. São Paulo: Idesp, 2002.

LAZZARINI, Sergio G. et al. Measuring trust: an experiment in Brazil. SSRN Working Paper. Disponível em: <http://papers.ssrn.com/sol3/papers.cfm? abstract_id $=484342>$. Acesso em: 30-6-2005. 
LUNDBERG, Eduardo Luis (Org.). Economia bancária e crédito: avaliação de 4 anos do projeto de juros e spread bancário no Brasil. Estudo do Departamento de Estudos e Pesquisas - DEPEP - do Banco Central do Brasil. Dezembro de 1999. Disponível em: <http://www.bcb.gov.br/ftp/rel_economia_bancaria_credito.pdf > .

MAURO, Paolo. Corruption and growth. The Quarterly Journal of Economics. v. 110, no 3, Aug. 1995, p. 681-712.

NORTH, Douglass C. Institutions, institutional change and economic performance. New York: Cambridge University Press, 1990.

. Understanding the process of economic change. Princeton: Princeton University Press, 2005.

PINHEIRO, Armando Castelar. O Judiciário e a Economia no Brasil. São Paulo: Idesp, 2000.

. Judiciário, reforma e economia: uma visão dos magistrados. 2002.

. O componente judicial dos spreads bancários. Economia bancária e crédito, Banco Central do Brasil, dezembro 2003.

POSNER, Richard. Overcoming law. Cambridge: Harvard University Press, 1995.

RIBEIRO, Ivan César. Concorrência bancária e determinantes institucionais da taxa de juros: uma análise empírica de séries de tempo. A ser publicado em Revista do IBRAC, 2006.

RIBEIRO, Ivan. Contratos relacionais e a Teoria da Firma: um teste empírico com a sub-contrataçāo de atividades jurídicas. Dissertação de Mestrado defendida na FEA/USP em 24 out. 2005, 2005a.

RIBEIRO, Ivan. Relações entre Judiciário, corrupção e desenvolvimento: o balanceamento entre desburocratização e a garantia do controle da atividade pública. Forthcoming in Controladoria Geral da União, premiados do I Concurso de Monografias (1 Lugar), 2005b. Disponível em: <http://www.cgu.gov.br/sfc/monografias/ arquivos/1.1.integra.pdf $>$.

SADEK, Maria Tereza. Pesquisa AMB 2005, 2005. Disponivel em: < http://www. amb.com.br/portal/docs/noticias/pesquisaamb2005.pdf $>$. Acesso em: 12 jan. 2006.

SANTISO, Carlos. The elusive quest for the rule of law: promoting judicial reform in Latin America. Brazilian Journal of Political Economy, v. 23, $\mathbf{n}^{\circ}$ 3, p. 112-134, 2003.

SEN, Amartya Kumar. Desenvolvimento como liberdade. São Paulo: Companhia das Letras, 2000. 
THURSTONE, L. L. The measurement of values. Chicago: University of Chicago Press, 1959.

VIANNA, Luiz Werneck et al. Corpo e alma da magistratura brasileira. Rio de Janeiro: Revan, 1997.

WHITE, $\mathrm{H}$. A Heteroskedasticity: consistent covariance matrix estimator and direct test for heteroskedasticity. Econometrica, v. 48, p. 817-838, 1980.

WILLIAMSON, O. E. The economic institutions of capitalism: firms, markets, relational contracts. New York: The Free Press, 1985.

The mechanisms of governance. New York: Oxford University Press, 1996.

WORLD BANK. Initiatives in legal and judicial reform. Disponível em: <http://www. worldbank.org/legal/publications/initiatives-final.pdf>. Acesso em 2004.

ZAFFARONI, Raúl. Dimensión política de um Poder Judicial democrático. Boletín, 37, Comissão Andina de Juristas, 1993.

Anexo I - Tabela de dados das decisões judiciais e medidas técnicas.

\begin{tabular}{|c|c|c|c|c|c|c|c|c|c|c|c|}
\hline $\begin{array}{l}\mathrm{N}^{2} \mathrm{da} \\
\text { Ocor- } \\
\text { rência }\end{array}$ & $\begin{array}{l}\text { Número } \\
\text { do } \\
\text { Acórdão }\end{array}$ & $\begin{array}{c}\text { Result. } \\
\text { da } \\
\text { Ação }\end{array}$ & Área & $\begin{array}{c}\text { Cód. } \\
\text { da } \\
\text { área }\end{array}$ & $\begin{array}{l}\text { Incid. de } \\
\text { Normas } \\
\text { Cogentes }\end{array}$ & $\begin{array}{l}\text { Parte } \\
\text { mais } \\
\text { Forte }\end{array}$ & $\begin{array}{l}\text { Prepond. } \\
\text { de Hipo }\end{array}$ & $\begin{array}{c}\text { Dummy } \\
\text { Hipo }\end{array}$ & $\begin{array}{c}\text { Interaçāo } \\
\text { Cogência } \\
\text { Parte Mais } \\
\text { Forte }\end{array}$ & $\begin{array}{l}\text { Interaçāo } \\
\text { da Cog. } \\
\text { e Hipo }\end{array}$ & $\begin{array}{c}\text { Interaçāo } \\
\text { da Cog. e } \\
\text { Interesse } \\
\text { Público }\end{array}$ \\
\hline 1 & 13511525 & 0 & Consumidor & I & 5,43 & 1 & 66.67 & I & 5,43 & 3,62 & 0 \\
\hline 2 & 762840 & 1 & Consumidor & I & 5,43 & 1 & 66.67 & 1 & 5,43 & 3,62 & 0 \\
\hline 3 & 812665 & 0 & Consumidor & I & 5.43 & I & 66.67 & 1 & 5,43 & 3,62 & 0 \\
\hline 4 & 816153 & 0 & Consumidor & 1 & 5.43 & I & 66.67 & 1 & 5,43 & 3,62 & 0 \\
\hline 5 & 816178 & 0 & Consumidor & 1 & 5.43 & I & 66,67 & 1 & 5,43 & 3,62 & 0 \\
\hline 6 & 817602 & 0 & Consumidor & 1 & 5,43 & I & 66.67 & 1 & 5.43 & 3.62 & 0 \\
\hline 7 & 839960 & I & Consumidor & 1 & 5,43 & 0 & 66.67 & 1 & 0 & 3,62 & 0 \\
\hline 8 & 839961 & 1 & Consumidor & 1 & 5.43 & I & 66,67 & 1 & 5.43 & 3,62 & 0 \\
\hline 10 & 840484 & 0 & Consumidor & 1 & 5.43 & I & 66,67 & 1 & 5.43 & 3.62 & 0 \\
\hline 11 & 840486 & 0 & Consumidor & 1 & 5,43 & 1 & 66,67 & 1 & 5.43 & 3,62 & 0 \\
\hline 12 & 815312 & 0 & Consumidor & 1 & 5,43 & 1 & 66.67 & 1 & 5.43 & 3.62 & 0 \\
\hline 13 & 840523 & 1 & Consumidor & 1 & 5,43 & 1 & 66.67 & 1 & 5,43 & 3,62 & 0 \\
\hline 14 & 843842 & I & Consumidor & 1 & 5,43 & 1 & 66.67 & I & 5.43 & 3.62 & 0 \\
\hline 15 & 844177 & 1 & Consumidor & 1 & 5,43 & 1 & 66.67 & I & 5.43 & 3.62 & 0 \\
\hline 16 & 817597 & 0 & Consumidor & 1 & 5.43 & 1 & 66,67 & 1 & 5,43 & 3.62 & 0 \\
\hline 17 & 837658 & 1 & Consumidor & 1 & 5.43 & 1 & 66.67 & 1 & & 3.62 & 0 \\
\hline 18 & 839748 & 0 & Consumidor & 1 & 5,43 & 1 & 66,67 & 1 & 5,43 & 3.62 & 0 \\
\hline 19 & 839795 & 0 & Consumidor & 1 & 5,43 & 1 & 66.67 & 1 & 5.43 & 3.62 & 0 \\
\hline 20 & 839945 & 0 & Consumidor & 1 & 5,43 & 1 & 66.67 & 1 & 5,43 & 3.62 & 0 \\
\hline
\end{tabular}




\begin{tabular}{|c|c|c|c|c|c|c|c|c|c|c|c|}
\hline $\begin{array}{l}N^{0} \text { da } \\
\text { Ocor- } \\
\text { rência }\end{array}$ & $\begin{array}{c}\text { Número } \\
\text { do } \\
\text { Acórdão }\end{array}$ & $\begin{array}{c}\text { Result. } \\
\text { da } \\
\text { Açāo }\end{array}$ & Área & $\begin{array}{c}\text { Cód. } \\
\text { da } \\
\text { área }\end{array}$ & $\begin{array}{l}\text { Incid. de } \\
\text { Normas } \\
\text { Cogentes }\end{array}$ & $\begin{array}{l}\text { Parte } \\
\text { mais } \\
\text { Forte }\end{array}$ & $\begin{array}{l}\text { Prepond. } \\
\text { de Hipo }\end{array}$ & $\begin{array}{c}\text { Dummy } \\
\text { Hipo }\end{array}$ & $\begin{array}{c}\text { Interação } \\
\text { Cogência } \\
\text { Parte Mais } \\
\text { Forte }\end{array}$ & $\begin{array}{c}\text { Interação } \\
\text { da Cog. } \\
\text { e Hipo }\end{array}$ & $\begin{array}{l}\text { Interaçāo } \\
\text { da Cog. e } \\
\text { Interesse } \\
\text { Público }\end{array}$ \\
\hline $2 !$ & 840308 & 0 & Consumidor & I & 5.43 & I & 66.67 & 1 & 5.43 & 3.62 & 0 \\
\hline 22 & 840323 & 0 & Consumidor & I & 5.43 & I & 66.67 & I & 5,43 & 3.62 & 0 \\
\hline 23 & 840341 & 0 & Consumidor & I & 5.43 & I & 66,67 & I & 5,43 & 3.62 & 0 \\
\hline 24 & 843911 & 0 & Consumidor & I & 5.43 & $!$ & 66.67 & 1 & 5,43 & 3.62 & 0 \\
\hline 25 & 843920 & 0 & Consumidor & 1 & 5.43 & 1 & 66.67 & 1 & 5.43 & 3.62 & 0 \\
\hline 26 & 840309 & 0 & Consumidor & 1 & 5,43 & 1 & 66.67 & 1 & 5.43 & 3,62 & 0 \\
\hline 27 & 840324 & 0 & Consumidor & 1 & 5,43 & 1 & 66,67 & 1 & 5.43 & 3.62 & 0 \\
\hline 28 & 840274 & 0 & Consumidor & I & 5,43 & I & 66.67 & 1 & 5.43 & 3.62 & 0 \\
\hline 29 & 840538 & 0 & Consumidor & 1 & 5,43 & I & 66.67 & I & 5,43 & 3.62 & 0 \\
\hline 30 & 843761 & 0 & Consumidor & I & 5,43 & I & 66,67 & 1 & 5,43 & 3.62 & 0 \\
\hline 31 & 813768 & 1 & Previdenciário & 2 & 6.03 & । & 13.33 & 0 & 6.03 & 0.8 & 6.03 \\
\hline 32 & 814138 & 0 & Previdenciário & 2 & 6.03 & । & 13.33 & 0 & 6,03 & 0.8 & 6.03 \\
\hline 33 & 814239 & 0 & Previdenciário & 2 & 6,03 & 0 & 13.33 & 0 & 0 & 0.8 & 6.03 \\
\hline 34 & 814324 & 1 & Previdenciário & 2 & 6.03 & I & 13.33 & 0 & 6.03 & 0.8 & 6.03 \\
\hline 35 & $8: 4574$ & 0 & Previdenciário & 2 & 6.03 & 0 & 13.33 & 0 & 0 & 0.8 & 6.03 \\
\hline 36 & 814665 & 0 & Previdenciário & 2 & 6.03 & 1 & 13.33 & 0 & 6.03 & 0.8 & 6.03 \\
\hline 37 & 814771 & 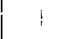 & Previdenciário & 2 & 6.03 & 1 & 13.33 & 0 & 6.03 & 0.8 & 6.03 \\
\hline 38 & 815117 & 0 & Previdenciário & 2 & 6.03 & 1 & 13.33 & 0 & 6.03 & 0.8 & 6,03 \\
\hline 39 & 817168 & 1 & Previdenciário & 2 & 6,03 & 0 & 13,33 & 0 & 0 & 0.8 & 6,03 \\
\hline 40 & 817208 & 0 & Previdenciáno & 2 & 6.03 & 0 & 13.33 & 0 & 0 & 0.8 & 6.03 \\
\hline 41 & 818423 & 0 & Previdenciário & 2 & 6.03 & I & 13.33 & 0 & 6.03 & 0.8 & 6.03 \\
\hline 42 & 818432 & 0 & Previdenciário & 2 & 6.03 & I & 13.33 & 0 & 6.03 & 0.8 & 6.03 \\
\hline 43 & 818440 & 1 & Previdenciário & 2 & 6.03 & 0 & 13.33 & 0 & 0 & 0.8 & 6.03 \\
\hline 44 & 818622 & 0 & Previdenciário & 2 & 6.03 & I & 13.33 & 0 & 6.03 & 0.8 & 6.03 \\
\hline 45 & $8 \mid 8673$ & 0 & Previdenciário & 2 & 6.03 & 1 & 13.33 & 0 & 6.03 & 0.8 & 6.03 \\
\hline 46 & 818847 & 0 & Previdenciário & 2 & 6.03 & 1 & 13.33 & 0 & 6.03 & 0.8 & 6.03 \\
\hline 47 & 818968 & 1 & Previdenciário & 2 & 6,03 & 1 & 13,33 & 0 & 6,03 & 0,8 & 6,03 \\
\hline 48 & 826607 & 0 & Previdenciário & 2 & 6.03 & 1 & 13.33 & 0 & 6.03 & 0.8 & 6.03 \\
\hline 49 & 826877 & 0 & Previdenciánio & 2 & 6.03 & 0 & 13,33 & 0 & 0 & 0.8 & 6,03 \\
\hline 50 & 828639 & 0 & Previdenciário & 2 & 6.03 & 1 & 13.33 & 0 & 6.03 & 0.8 & 6.03 \\
\hline 51 & 828808 & 0 & Previdenciário & 2 & 6.03 & 1 & 13,33 & 0 & 6,03 & 0.8 & 6,03 \\
\hline 52 & $8288 i 8$ & 0 & Previdenciário & 2 & 6.03 & I & 13.33 & 0 & 6.03 & 0.8 & 6.03 \\
\hline 53 & 828820 & 0 & Previdenciáno & 2 & 5.03 & I & 13.33 & 0 & 6,03 & 0,8 & 6.03 \\
\hline 54 & 841800 & 0 & Previdenciário & 2 & 6.03 & I & 13.33 & 0 & 6,03 & 0.8 & 6.03 \\
\hline 56 & 842116 & 0 & Previdenciário & 2 & 6.03 & I & 13.33 & 0 & 6.03 & 0.8 & 6.03 \\
\hline 57 & 842530 & 0 & Previdenciário & 2 & 6,03 & 1 & 13.33 & 0 & 6.03 & 0.8 & 6.03 \\
\hline 58 & 845149 & 0 & Previdenciário & 2 & 6.03 & 1 & 13.33 & 0 & 6.03 & 0.8 & 6.03 \\
\hline 59 & 846063 & 0 & Previdenciário & 2 & 6,03 & 1 & 13,33 & 0 & 6,03 & 0,8 & 6.03 \\
\hline
\end{tabular}




\begin{tabular}{|c|c|c|c|c|c|c|c|c|c|c|c|}
\hline $\begin{array}{l}N^{2} \text { da } \\
\text { Ocor- } \\
\text { rência }\end{array}$ & $\begin{array}{c}\text { Número } \\
\text { do } \\
\text { Acórdāo }\end{array}$ & $\begin{array}{c}\text { Result. } \\
\text { da } \\
\text { Ação }\end{array}$ & Área & $\begin{array}{c}\text { Cód. } \\
\text { da } \\
\text { área }\end{array}$ & $\begin{array}{l}\text { Incid. de } \\
\text { Normas } \\
\text { Cogentes }\end{array}$ & $\begin{array}{l}\text { Parte } \\
\text { mais } \\
\text { Forte }\end{array}$ & $\begin{array}{l}\text { Prepond. } \\
\text { de Hipo }\end{array}$ & $\begin{array}{c}\text { Dummy } \\
\text { Hipo }\end{array}$ & $\begin{array}{c}\text { Interaçāo } \\
\text { Cogência } \\
\text { Parte Mais } \\
\text { Forte }\end{array}$ & $\begin{array}{c}\text { Interaçāo } \\
\text { da Cog. } \\
\text { e Hipo }\end{array}$ & $\begin{array}{c}\text { Interaçāo } \\
\text { da Cog. e } \\
\text { Interesse } \\
\text { Público }\end{array}$ \\
\hline 60 & 846823 & 0 & Previdenciário & 2 & 6.03 & 1 & 13,33 & 0 & 6,03 & 0.8 & 6.03 \\
\hline 61 & 20050409624 & 0 & Trabalhista & 3 & 5,94 & 1 & 66.67 & 1 & 5,94 & 3,96 & 0 \\
\hline 62 & 20050403553 & I & Trabalhista & 3 & 5.94 & 0 & 66.67 & I & 0 & 3.96 & 0 \\
\hline 63 & 20050401801 & 0 & Trabalhista & 3 & 5.94 & 1 & 66,67 & I & 5.94 & 3.96 & 0 \\
\hline 64 & 20050392179 & । & Trabalhista & 3 & 5,94 & 0 & 66,67 & 1 & 0 & 3.96 & 0 \\
\hline 65 & 20050375932 & 0 & Trabalhista & 3 & 5.94 & 1 & 66.67 & I & 5.94 & 3.96 & 0 \\
\hline 66 & 20050318149 & 0 & Trabalhista & 3 & 5,94 & 1 & 66,67 & I & 5.94 & 3.96 & 0 \\
\hline 67 & 20050310113 & 0 & Trabalhista & 3 & 5.94 & 1 & 66,67 & 1 & 5.94 & 3.96 & 0 \\
\hline 68 & 20050189330 & 1 & Trabalhista & 3 & 5.94 & 1 & 66.67 & 1 & 5.94 & 3.96 & 0 \\
\hline 69 & 20050134102 & 0 & Trabalhista & 3 & 5.94 & I & 66.67 & 1 & 5.94 & 3.96 & 0 \\
\hline 70 & 20050121043 & 0 & Trabalhista & 3 & 5.94 & 1 & 66,67 & 1 & 5,94 & 3.96 & 0 \\
\hline 71 & 20040386931 & 0 & Trabalhista & 3 & 5.94 & 1 & 66.67 & 1 & 5,94 & 3.96 & 0 \\
\hline 72 & 20050415098 & I & Trabalhista & 3 & 5,94 & 1 & 66.67 & 1 & 5,94 & 3.96 & 0 \\
\hline 73 & $200504 \mid 2323$ & 0 & Trabalhista & 3 & 5.94 & 1 & 66.67 & I & 5.94 & 3,96 & 0 \\
\hline 74 & 20050026970 & 0 & Trabalhista & 3 & 5.94 & 1 & 66,67 & 1 & 5.94 & 3.96 & 0 \\
\hline 75 & 20040513860 & 0 & Trabalhista & 3 & 5.94 & 1 & 66,67 & 1 & 5.94 & 3.96 & 0 \\
\hline 76 & 20040671270 & 0 & Trabalhista & 3 & 5.94 & 1 & 66,67 & 1 & 5,94 & 3.96 & 0 \\
\hline 77 & 20040526383 & 0 & Trabalhista & 3 & 5.94 & 1 & 66.67 & 1 & 5.94 & 3.96 & 0 \\
\hline 78 & 20040535660 & 0 & Trabalhista & 3 & 5.94 & I & 66.67 & 1 & 5.94 & 3.96 & 0 \\
\hline 79 & 20040298960 & 0 & Trabalhista & 3 & 5.94 & I & 66.67 & 1 & 5,94 & 3,96 & 0 \\
\hline 80 & 20040212631 & 0 & Trabalhista & 3 & 5.94 & I & 66.67 & I & 5,94 & 3.96 & 0 \\
\hline 81 & 20040212038 & 0 & Trabalhista & 3 & 5.94 & 1 & 66.67 & I & 5.94 & 3.96 & 0 \\
\hline 82 & 12862034 & । & Comercial & 4 & 1.68 & 1 & 0 & 0 & 1,68 & 0 & 1,68 \\
\hline 83 & 7192880 & 1 & Comercial & 4 & 1.68 & & 0 & 0 & & 0 & 1,68 \\
\hline 84 & 8509970 & 0 & Comercial & 4 & 1.68 & & 0 & 0 & & 0 & 1,66 \\
\hline 85 & 8671090 & 1 & Comercial & 4 & 1.68 & & 0 & 0 & & 0 & 1,68 \\
\hline 86 & 8822170 & 1 & Comercial & 4 & 1.68 & & 0 & 0 & & 0 & 1,68 \\
\hline 87 & 8875120 & । & Comercial & 4 & 1.68 & & 0 & 0 & & 0 & 1,68 \\
\hline 88 & 9412395 & । & Comercial & 4 & 1,68 & & 0 & 0 & & 0 & 1.68 \\
\hline 89 & 812606 & । & Comercial & 4 & 1.68 & & 0 & 0 & & 0 & 1.68 \\
\hline 90 & 827087 & I & Comercial & 4 & 1,68 & 0 & 0 & 0 & 0 & 0 & 1,68 \\
\hline $9 !$ & 811614 & 1 & Comercial & 4 & 1.68 & & 0 & 0 & & 0 & 1,68 \\
\hline 92 & 815379 & 1 & Comercial & 4 & 1,68 & 0 & 0 & 0 & 0 & 0 & 1,68 \\
\hline 93 & 844606 & 1 & Comercial & 4 & 1.68 & & 0 & 0 & & 0 & 1,68 \\
\hline 94 & 6935580 & I & Comercial & 4 & 1.68 & & 0 & 0 & & 0 & 1,68 \\
\hline 95 & 6944070 & 1 & Comercial & 4 & 1,68 & I & 0 & 0 & 1,68 & 0 & 1,68 \\
\hline 96 & 7991520 & I & Comercial & 4 & 1.68 & & 0 & 0 & & 0 & 1.68 \\
\hline 97 & 8901697 & $!$ & Comercial & 4 & 1.68 & & 0 & 0 & & 0 & 1,68 \\
\hline
\end{tabular}


76 Revista de Direito Administrativo

\begin{tabular}{|c|c|c|c|c|c|c|c|c|c|c|c|}
\hline $\begin{array}{l}\mathbf{N}^{2} \text { da } \\
\text { Ocor- } \\
\text { rência }\end{array}$ & $\begin{array}{c}\text { Número } \\
\text { do } \\
\text { Acórdāo }\end{array}$ & $\begin{array}{c}\text { Result. } \\
\text { da } \\
\text { Ação }\end{array}$ & Área & $\begin{array}{c}\text { Cód. } \\
\text { da } \\
\text { área }\end{array}$ & $\begin{array}{l}\text { Incid. de } \\
\text { Normas } \\
\text { Cogentes }\end{array}$ & $\begin{array}{l}\text { Parte } \\
\text { mais } \\
\text { Forte }\end{array}$ & $\begin{array}{l}\text { Prepond. } \\
\text { de Hipo }\end{array}$ & $\begin{array}{c}\text { Dummy } \\
\text { Hipo }\end{array}$ & $\begin{array}{c}\text { Interaçäo } \\
\text { Cogência } \\
\text { Parte Mais } \\
\text { Forte }\end{array}$ & $\begin{array}{l}\text { Interaçäo } \\
\text { da Cog. } \\
\text { e Hipo }\end{array}$ & $\begin{array}{l}\text { Interaçāo } \\
\text { da Cog. e } \\
\text { Interesse } \\
\text { Público }\end{array}$ \\
\hline 98 & 8872806 & 1 & Comercial & 4 & 1,68 & & 0 & 0 & & 0 & 1,68 \\
\hline 99 & 693066 & 1 & Regulaçāo & 5 & 5.23 & & 0 & 0 & & 0 & 5.23 \\
\hline 100 & 695531 & 1 & Regulaçāo & 5 & 5,23 & & 0 & 0 & & 0 & 5.23 \\
\hline 101 & 707568 & 0 & Regulaçāo & 5 & 5.23 & & 0 & 0 & & 0 & 5.23 \\
\hline 102 & 707569 & 0 & Regulaçāo & 5 & 5.23 & & 0 & 0 & & 0 & 5.23 \\
\hline 103 & 735025 & 0 & Regulaçāo & 5 & 5,23 & 1 & 0 & 0 & 5,23 & 0 & 5.23 \\
\hline 104 & 741249 & 1 & Regulaçāo & 5 & 5.23 & & 0 & 0 & & 0 & 5,23 \\
\hline 105 & $8|467|$ & 0 & Regulaçäo & 5 & 5.23 & & 0 & 0 & & 0 & 5.23 \\
\hline 106 & 825485 & 0 & Regulaçāo & 5 & 5,23 & & 0 & 0 & & 0 & 5,23 \\
\hline 107 & 814887 & 0 & Regulação & 5 & 5.23 & & 0 & 0 & & 0 & 5,23 \\
\hline 108 & 845788 & 1 & Regulaçāo & 5 & 5,23 & & 0 & 0 & & 0 & 5.23 \\
\hline 109 & 829302 & 0 & Regulaçāo & 5 & 5,23 & 1 & 0 & 0 & 5.23 & 0 & 5,23 \\
\hline 111 & 837589 & 0 & Regulaçāo & 5 & 5,23 & & 0 & 0 & & 0 & 5,23 \\
\hline 112 & 6536060 & 1 & Inquilinato & 6 & 2,94 & & 26.67 & 0 & & 0.78 & 2.94 \\
\hline 113 & 6584590 & 0 & Inquilinato & 6 & 2,94 & & 26,67 & 0 & & 0,78 & 2,94 \\
\hline 114 & 6670000 & 0 & Inquilinato & 6 & 2,94 & 1 & 26,67 & 0 & 2,94 & 0.78 & 2,94 \\
\hline 115 & 6917740 & 1 & Inquilinato & 6 & 2,94 & & 26.67 & 0 & & 0.78 & 2.94 \\
\hline 116 & 6989940 & 0 & Inquilinato & 6 & 2.94 & 1 & 26.67 & 0 & 2,94 & 0,78 & 2,94 \\
\hline 117 & 7003940 & 1 & Inquilinato & 6 & 2,94 & & 26,67 & 0 & & 0,78 & 2,94 \\
\hline 118 & 7108110 & 1 & Inquilinato & 6 & 2.94 & & 26.67 & 0 & & 0.78 & 2,94 \\
\hline 119 & 7166330 & 1 & Inquilinato & 6 & 2.94 & & 26.67 & 0 & & 0.78 & 2,94 \\
\hline 120 & 7258230 & 1 & Inquilinato & 6 & 2,94 & & 26.67 & 0 & & 0,78 & 2,94 \\
\hline $12 \mid$ & 7270990 & 1 & Inquilinato & 6 & 2.94 & 1 & 26.67 & 0 & 2.94 & 0.78 & 2,94 \\
\hline 122 & 7381320 & 1 & Inquilinato & 6 & 2,94 & & 26,67 & 0 & & 0,78 & 2,94 \\
\hline 123 & $7437 \mid 40$ & 0 & Inquilinato & 6 & 2.94 & & 26,67 & 0 & & 0,78 & 2,94 \\
\hline 124 & 7451970 & 1 & Inquilinato & 6 & 2.94 & & 26,67 & 0 & & 0.78 & 2.94 \\
\hline 125 & 7585590 & 1 & Inquilinato & 6 & 2,94 & & 26.67 & 0 & & 0.78 & 2,94 \\
\hline 126 & 7627850 & 0 & Inquilinato & 6 & 2.94 & 1 & 26.67 & 0 & 2.94 & 0.78 & 2.94 \\
\hline 127 & 7697240 & I & Inquilinato & 6 & 2,94 & & 26,67 & 0 & & 0,78 & 2,94 \\
\hline 128 & 7723080 & I & Inquilinato & 6 & 2,94 & 0 & 26.67 & 0 & 0 & 0,78 & 2,94 \\
\hline 129 & 7763820 & 1 & Inquilinato & 6 & 2.94 & & 26.67 & 0 & & 0,78 & 2.94 \\
\hline 130 & 7775500 & 0 & Inquilinato & 6 & 2,94 & & 26.67 & 0 & & 0,78 & 2.94 \\
\hline 131 & 7869190 & 1 & Inquilinato & 6 & 2.94 & & 26.67 & 0 & & 0,78 & 2.94 \\
\hline 132 & 7928720 & 1 & Inquilinato & 6 & 2,94 & & 26,67 & 0 & & 0,78 & 2,94 \\
\hline 133 & 8044860 & I & Inquilinato & 6 & 2.94 & & 26,67 & 0 & & 0.78 & 2.94 \\
\hline 134 & 8122370 & 0 & Inquilinato & 6 & 2,94 & 0 & 26,67 & 0 & 0 & 0,78 & 2.94 \\
\hline 135 & 8146380 & 1 & Inquilinato & 6 & 2,94 & & 26,67 & 0 & & 0,78 & 2,94 \\
\hline 136 & 8189260 & 1 & Inquilinato & 6 & 2,94 & & 26,67 & 0 & & 0,78 & 2.94 \\
\hline
\end{tabular}




\begin{tabular}{|c|c|c|c|c|c|c|c|c|c|c|c|}
\hline $\begin{array}{l}\mathbf{N}^{2} \mathrm{da} \\
\text { Ocor- } \\
\text { rência }\end{array}$ & $\begin{array}{c}\text { Número } \\
\text { do } \\
\text { Acórdāo }\end{array}$ & $\begin{array}{c}\text { Result. } \\
\text { da } \\
\text { Açāo }\end{array}$ & Área & $\begin{array}{c}\text { Cod. } \\
\text { d } \\
\text { área }\end{array}$ & $\begin{array}{l}\text { Incid. de } \\
\text { Normas } \\
\text { Cogentes }\end{array}$ & $\begin{array}{l}\text { Parte } \\
\text { mais } \\
\text { Forte }\end{array}$ & $\begin{array}{l}\text { Prepond. } \\
\text { de Hipo }\end{array}$ & $\begin{array}{c}\text { Dummy } \\
\text { Hipo }\end{array}$ & $\begin{array}{c}\text { Interaçä } \\
\text { Cogência } \\
\text { Parte Mais } \\
\text { Forte }\end{array}$ & $\begin{array}{c}\text { Interaçso } \\
\text { da Cog. } \\
\text { e Hipo }\end{array}$ & $\begin{array}{l}\text { Interaçäo } \\
\text { da Cog. e } \\
\text { Interesse } \\
\text { Público }\end{array}$ \\
\hline 137 & 8210330 & 1 & Inquilinato & 6 & 2,94 & & 26,67 & 0 & & 0,78 & 2,94 \\
\hline 138 & 8332870 & 1 & Inquilinato & 6 & 2,94 & & 26.67 & 0 & & 0,78 & 2,94 \\
\hline 139 & 8364860 & 1 & Inquilinato & 6 & 2.94 & 1 & 26.67 & 0 & 2.94 & 0.78 & 2.94 \\
\hline 140 & 8395040 & 0 & Inquilinato & 6 & 2.94 & 1 & 26,67 & 0 & 2,94 & 0,78 & 2,94 \\
\hline 141 & 8405400 & 1 & Inquilinato & 6 & 2,94 & 0 & 26,67 & 0 & 0 & 0,78 & 2.94 \\
\hline 142 & 829329 & 0 & Ambiental & 7 & 6.53 & & 0 & 0 & & 0 & 6.53 \\
\hline 143 & 805509 & 0 & Ambiental & 7 & 6.53 & & 0 & 0 & & 0 & 6.53 \\
\hline 144 & 805906 & 0 & Ambiental & 7 & 6.53 & & 0 & 0 & & 0 & 6,53 \\
\hline 145 & 766916 & 0 & Ambiental & 7 & 6.53 & 0 & 0 & 0 & 0 & 0 & 6.53 \\
\hline 146 & $81 \mid 327$ & 0 & Ambiental & 7 & 6.53 & & 0 & 0 & & 0 & 6,53 \\
\hline 147 & 843837 & 0 & Ambiental & 7 & 6.53 & $I$ & 0 & 0 & 6.53 & 0 & 6.53 \\
\hline 148 & 11229324 & 0 & Ambiental & 7 & 6.53 & 0 & 0 & 0 & 0 & 0 & 6.53 \\
\hline 149 & 9893572 & 0 & Ambiental & 7 & 6.53 & 1 & 0 & 0 & 6.53 & 0 & 6.53 \\
\hline 150 & 5674900 & 0 & Ambiental & 7 & 6.53 & 0 & 0 & 0 & 0 & 0 & 6,53 \\
\hline 151 & 826476 & 0 & Ambiental & 7 & 6.53 & & 0 & 0 & & 0 & 6.53 \\
\hline 152 & 766755 & 0 & Ambiental & 7 & 6.53 & 0 & 0 & 0 & 0 & 0 & 6,53 \\
\hline 153 & 825494 & 0 & Ambiental & 7 & 6,53 & 0 & 0 & 0 & 0 & 0 & 6,53 \\
\hline 154 & 819091 & 0 & Ambiental & 7 & 6.53 & 0 & 0 & 0 & 0 & 0 & 6,53 \\
\hline 155 & 9482862 & 1 & Crédito & 8 & 2,32 & 1 & 0 & 0 & 2.32 & 0 & 2.32 \\
\hline 156 & 839593 & 0 & Crédito & 8 & 2.32 & 0 & 0 & 0 & 0 & 0 & 2,32 \\
\hline 157 & 839984 & 1 & Crédito & 8 & 2.32 & 1 & 0 & 0 & 2.32 & 0 & 2,32 \\
\hline 158 & 840493 & I & Crédito & 8 & 2,32 & 1 & 0 & 0 & 2,32 & 0 & 2.32 \\
\hline 159 & 6522890 & I & Crédito & 8 & 2,32 & 1 & 0 & 0 & 2,32 & 0 & 2,32 \\
\hline 160 & 8947250 & 1 & Crédito & 8 & 2,32 & & 0 & 0 & & 0 & 2.32 \\
\hline 161 & 6935580 & 1 & Crédito & 8 & 2,32 & I & 0 & 0 & 2,32 & 0 & 2,32 \\
\hline 162 & 6924360 & 1 & Crédito & 8 & 2,32 & 1 & 0 & 0 & 2,32 & 0 & 2.32 \\
\hline 163 & 6552970 & 0 & Crédito & 8 & 2.32 & 0 & 0 & 0 & 0 & 0 & 2,32 \\
\hline 164 & 8664868 & 1 & Crédito & 8 & 2,32 & 1 & 0 & 0 & 2,32 & 0 & 2,32 \\
\hline 165 & 8100465 & 1 & Crédito & 8 & 2,32 & 1 & 0 & 0 & 2,32 & 0 & 2,32 \\
\hline 166 & 9424433 & 1 & Crédito & 8 & 2.32 & 1 & 0 & 0 & 2,32 & 0 & 2,32 \\
\hline 167 & 8600693 & 0 & Crédito & 8 & 2.32 & 1 & 0 & 0 & 2.32 & 0 & 2,32 \\
\hline 168 & 9245663 & । & Crédito & 8 & 2,32 & & 0 & 0 & & 0 & 2,32 \\
\hline 169 & 8872806 & I & Crédito & 8 & 2,32 & 0 & 0 & 0 & 0 & 0 & 2,32 \\
\hline 170 & 8709280 & 0 & Crédito & 8 & 2.32 & 0 & 0 & 0 & 0 & 0 & 2.32 \\
\hline 171 & 8787282 & 1 & Crédito & 8 & 2,32 & 1 & 0 & 0 & 2,32 & 0 & 2,32 \\
\hline 172 & 12589970 & 1 & Crédito & 8 & 2.32 & 1 & 0 & 0 & 2,32 & 0 & 2.32 \\
\hline 173 & 8636277 & 1 & Crédito & 8 & 2,32 & 1 & 0 & 0 & 2,32 & 0 & 2.32 \\
\hline 174 & 8608922 & 1 & Crédito & 8 & 2,32 & 0 & 0 & 0 & & 0 & 2,32 \\
\hline
\end{tabular}




\begin{tabular}{|c|c|c|c|c|c|c|c|c|c|c|c|}
\hline $\begin{array}{l}N^{\circ} \text { da } \\
\text { Ocor- } \\
\text { rência }\end{array}$ & $\begin{array}{c}\text { Número } \\
\text { do } \\
\text { Acórdāo }\end{array}$ & $\begin{array}{c}\text { Result. } \\
\text { da } \\
\text { Ação }\end{array}$ & Área & $\begin{array}{c}\text { Cód. } \\
\text { da } \\
\text { área }\end{array}$ & $\begin{array}{l}\text { Incid. de } \\
\text { Normas } \\
\text { Cogentes }\end{array}$ & $\begin{array}{l}\text { Parte } \\
\text { mais } \\
\text { Forte }\end{array}$ & $\begin{array}{l}\text { Prepond. } \\
\text { de Hipo }\end{array}$ & $\begin{array}{c}\text { Dummy } \\
\text { Hipo }\end{array}$ & $\begin{array}{c}\text { Interaçāo } \\
\text { Cogência } \\
\text { Parte Mais } \\
\text { Forte }\end{array}$ & $\begin{array}{l}\text { Interaçāo } \\
\text { da Cog. } \\
\text { e Hipo }\end{array}$ & $\begin{array}{l}\text { Interaçāo } \\
\text { da Cog. e } \\
\text { Interesse } \\
\text { Público }\end{array}$ \\
\hline 175 & 8539224 & 1 & Crédito & 8 & 2.32 & 1 & 0 & 0 & 2.32 & 0 & 2,32 \\
\hline 176 & 8466571 & I & Crédito & 8 & 2.32 & 1 & 0 & 0 & 2.32 & 0 & 2.32 \\
\hline 177 & 7993595 & I & Crédito & 8 & 2.32 & I & 0 & 0 & 2.32 & 0 & 2.32 \\
\hline 178 & $8676: 08$ & 1 & Crédito & 8 & 2.32 & 1 & 0 & 0 & 2.32 & 0 & 2.32 \\
\hline 179 & 8379368 & 1 & Crédito & 8 & 2.32 & 1 & 0 & 0 & 2,32 & 0 & 2.32 \\
\hline 180 & 9084031 & 1 & Crédito & 8 & 2.32 & 1 & 0 & 0 & 2.32 & 0 & 2.32 \\
\hline 181 & 8703273 & 1 & Crédito & 8 & 2.32 & 1 & 0 & 0 & 2.32 & 0 & 2.32 \\
\hline 182 & 8333526 & 1 & Crédito & 8 & 2.32 & 1 & 0 & 0 & 2.32 & 0 & 2.32 \\
\hline 183 & 8651085 & 1 & Crédito & 8 & 2.32 & I & 0 & 0 & 2.32 & 0 & 2.32 \\
\hline 184 & 13195607 & I & Crédito & 8 & 2.32 & 1 & 0 & 0 & 2.32 & 0 & 2,32 \\
\hline
\end{tabular}

Anexo II - Modelo de análise jurisprudencial.

O recorte temporal para a seleção dos acórdãos compreendeu os anos de 2005 e 2004. Esse recorte justifica-se por sua atualidade e por ser suficiente o número de acórdāos deste período que versam sobre as matérias em análise para compor a amostra aleatória selecionada. Também se pretende evitar o problema da correlação serial dos erros que uma amostra de período maior traria.

O material foi selecionado a partir dos bancos de dados dos seguintes tribunais, nos seus respectivos sites: 1) Tribunal de Justiça de São Paulo (www.tj.sp. gov.br), 2) antigo Primeiro Tribunal de Alçada de São Paulo (www.ptac.gov.br), 3) antigo Segundo Tribunal de Alçada de São Paulo (www.stac.gov.br) e 4) Tribunal Regional do Trabalho de São Paulo (www.trt02.gov.br).

Para a seleção das decisōes foram utilizadas as seguintes palavras chaves:

i) "anulação contratual", ii) "revisão contratual", iii) "alteração contratual", iv) "contrato empresarial", v) "contrato comercial", vi) "nulidade contratual", vii) "cláusula contratual", viii) "contrato de locação", ix) "locador", x) "locatário", xi) "fiador", xii) "resilição contratual", xiii) "contrato de crédito", xiv) "juros", xv) "instituiçāo financeira", xvi) "bancos", xvii) "consumidor", xviii) "Código de Defesa do Consumidor", xix) "hipossuficiência", xx) "meio ambiente", xxi) "danos ambientais", xxii) "desmatamento", xxiii) "poluição", xxiv) "área de preservação", xxv) "contrato de trabalho", xxvi) "acordo coletivo", xxvii) "convenção coletiva", xxviii) "contrato social", xxix) "banco central", xxx) "sociedade limitada", xxxi) "sociedade por quotas", xxxii) "sócios", xxxiii) "financiamento habitacional", xxxiv) "financiamento de imóveis", xxxv) "cartão de crédito", xxxvi) "anatocismo", xxxvii) "cheque", xxxviii) "contrato de leasing", xxxix) "alienação fiduciária", xl) "previdência privada", xli) "previdência", xlii) 
"aposentadoria", xliii) "pensão", xliv) "regulação de serviços públicos", xlv) "serviços públicos", xlvi) "concessão de serviços públicos", xlvii) "licitação". ${ }^{20}$

Por meio desse procedimento, foram localizados 1.019 acórdãos, dos quais 320 estavam compreendidos no objeto de estudo delimitado. ${ }^{21}$ Através da releitura cuidadosa de cada acórdão, a amostra da pesquisa foi reduzida para 181 decisões colegiadas. Os acórdãos restantes (139) foram excluídos por repetirem decisões já selecionadas, o que poderia comprometer a análise a ser realizada posteriormente.

A análise dos acórdãos foi qualitativa, procurando identificar os argumentos trazidos pelos julgadores na manutençāo ou afastamento do contrato celebrado entre as partes litigantes, e quantitativa, apurando qual tipo de decisão predominou em cada área selecionada no periodo analisado e sua relação com a maior ou menor quantidade de normas cogentes percebidas pelos magistrados nas respectivas áreas. Com estas análises se buscou aferir se quando os juízes afastam os contratos eles o fazem devido ao fato dos contratos violarem normas cogentes ou por mera liberalidade. Para tanto, foi desenvolvido um modelo ${ }^{22}$ de análise, com os seguintes itens investigativos:

(i) número do acórdão, Câmara ou Turma ${ }^{23}$ Foro e Ementa;

(ii) área do direito a qual pertence;

(iii) identificação das partes e da existência de parte em desvantagem; ${ }^{24}$

(iv) aferição se contrato beneficia parte em desvantagem ou em vantagem;

(v) prevalência ou afastamento do contrato;

(vi) transcrição dos trechos dos acórdãos para a aferição de cada classificação acima e fundamentação dada pelo magistrado.

Com a definição dos itens $i$ e ii, procurou-se identificar individualmente cada acórdão e classificá-lo em sua respectiva área do direito. No item iii, por sua vez,

\footnotetext{
A expressão contrato de foi substituída também pela expressão contratual, p. ex., locação contratual e vice e versa.

21 Uma das maiores dificuldades da pesquisa foi selecionar acórdãos em que houvesse a discussão de uma relação contratual referente a cada área selecionada. Em áreas como meio-ambiente, por exemplo, o autor da açāo na maioria das vezes era o Ministério Público, que objetivava proteger a coletividade contra um dano ambiental. As partes contratantes não estavam em litígio diretamente.

22 Ver modelo preenchido no Anexo II.

23 A classificaçāo em Câmara de Julgamento ou Turma de Julgamento se faz presente, pois se está trabalhando com tribunais diferentes. No Tribunal de Justiça de São Paulo utiliza-se a denominação Câmara e no Tribunal Regional do Trabalho adota-se a expressão Turma.

24 A expressão parte em desvantagem foi utilizada para designar a parte que tem menores condiçōes econômicas. Evitou-se a utilização da expressāo parte hipossuficiente, pois esta é definida legalmente e excluiria da apreciação relaçōes entre grandes e pequenas empresas, por exemplo.
} 
buscou-se identificar quais partes estavam envolvidas na demanda, servindo este item também como fundamento para a classificação da existência ou não de parte menos favorecida no processo. No item iv, objetivou-se analisar, na condição de existirem partes em condiçōes desiguais, quem o contrato ou a cláusula contratual discutida beneficiava. $\mathrm{O}$ item $v$ procurou verificar se $o$ julgador decidiu pela prevalência do contrato celebrado pelas partes na solução do conflito ou se ele afastou o contrato. Finalmente, no item $v i$ buscou-se transcrever os trechos dos acórdãos analisados para que se pudesse verificar qual foi a fundamentação utilizada pelo julgador em sua decisão e os critérios utilizados para as classificações dos itens iv e $v$.

As entrevistas foram realizadas no mês de agosto de 2005, no Tribunal de Justiça de São Paulo, tendo como respondentes 30 desembargadores. A amostra de juízes foi escolhida de forma aleatória. Todas as entrevistas foram realizadas pelos autores e tiveram duração de 15 a 30 minutos.

O questionário ${ }^{25}$ aplicado objetivou obter uma informação técnica dos juízes quanto à proporção de normas cogentes nas áreas especificadas. Como se trata de uma informação técnica e não de uma pesquisa de opinião, não houve necessidade de estratificação da amostra. A escolha deste universo de respondentes justifica-se à medida que, sendo o cargo de desembargador o mais elevado na carreira da magistratura, ${ }^{26}$ estes magistrados apresentam melhores condições de responder sobre matérias diversas, pois há maior probabilidade de já terem atuado em várias áreas.

O modelo de formulário aplicado é composto de seis partes, que serão descritas a seguir:

1. Exemplificação de normas cogentes incidentes sobre uma relação contratual para cada área relacionada.

2. Identificação do principal motivo da existência destas normas cogentes para cada área.

3. Identificação da área de maior e da de menor incidência de normas cogentes.

4. Indicação da maior ou menor existência de normas cogentes a limitar a liberdade de contratação das partes relativamente a cada área em uma escala de 1 a 7 (Thurstone, 1959, p. 39-49).

5. Dados demográficos: (a) sexo; (b) tempo de atividade profissional como juiz e (c) idade.

6. Posicionamento político e partido com que mais se identifica.

\footnotetext{
25 Ver Anexo III.

26 Excluem-se os cargos de ministros do Superior Tribunal de Justiça e do Supremo Tribunal de Justiça por serem cargos que necessitam de indicação política.
} 
Através do item 1, buscou-se verificar se os magistrados atribuem o mesmo significado para normas cogentes e fazê-los refletir sobre a existência dessas normas nas diversas áreas. O segundo item procurou constatar como os juízes compreendem a necessidade da existência de normas inafastáveis pela vontade das partes, dadas as especificidades de cada área do direito. No item 3, objetivouse fazer com que o magistrado estabelecesse pontos extremos quanto à incidência das normas cogentes em cada área para que este parâmetro fosse utilizado relativamente às outras áreas. $\mathrm{O}$ quarto item buscou aferir qual a quantidade relativa de normas cogentes em cada área, determinando inversamente qual a liberdade de contratação ou de livre disposição do particular de seu direito de contratar em cada área. No item 5, foram coletados dados demográficos com o intuito de verificar as características dos entrevistados e possível influência destas características em sua opinião. Finalmente, no item 6 objetivou-se aferir o perfil político do magistrado com o mesmo intuito do item 5 .

\begin{tabular}{|c|}
\hline Modelo de análise jurisprudencial \\
\hline Órgão julgador: Tribunal de Justiça de São Paulo \\
\hline Área do direito: Consumidor \\
\hline N Acórdāo e Câmara ou Turma: 816153 - 10ª Câmara \\
\hline $\begin{array}{l}\text { Ementa: } \\
\text { Seguro Saúde - Cláusula de exclusāo de aparelho de prótese - Cirurgia de emergência } \\
\text { realizada pelo marido da autora, sendo necessária colocaçāo de prótese aorto bilica por via en- } \\
\text { doluminal - Contrato de adesão submetido aos ditames do Código de Defesa do Consumidor } \\
\text { - Cláusula que é considerada abusiva e, portanto, tida como nāo escrita - Doutrina e jurispru- } \\
\text { dência - Reembolso devido à autora - Ação procedente - Recurso provido. }\end{array}$ \\
\hline $\begin{array}{l}\text { Identificação das partes e aferição da existência de parte em desvantagem: sim } \\
\text { Apelante: Maria Aparecida da Silva } \\
\text { Apelado: Itaú Seguros S.A. }\end{array}$ \\
\hline $\begin{array}{l}\text { Contrato favorece parte em vantagem ou parte em desvantagem: favorece parte em vantagem } \\
\text { "Do exame do instrumento de fls. } 9 / 10 \text {, infere-se que o ajuste se apresenta como um } \\
\text { típico 'contrato padrão', cujas cláusulas são pré-estipuladas pelo apelado, não restando a apelante } \\
\text { sequer, ao que parece, completar os espaços em branco." }\end{array}$ \\
\hline $\begin{array}{l}\text { "O fato é que a questionada cláusula de exclusão dos aparelhos protéticos (letra i do item } \\
\text { despesas excluídas - fls. 10), em face da lei, fica infirmada diante das exageradas vantagens irro- } \\
\text { gadas ao apelado em detrimento da apelante, ameaçando, destarte, o equilíbrio contratual, em } \\
\text { sendo leonina." }\end{array}$ \\
\hline Prevalência ou afastamento do contrato: afastamento \\
\hline $\begin{array}{l}\text { "Ademais, o artigo } 51 \text { do CDC, expressamente, dispōe que: 'sāo nulas de pleno direito, } \\
\text { entre outras, as cláusulas contratuais relativas ao fornecimento de produtos e senviços que [...] } \\
\text { IV - estabeleçam obrigaçōes consideradas iníquas, abusivas, que coloquem o consumidor em } \\
\text { desvantagem exagerada, ou seja, incompatíveis com a boa-fé ou a equidade'. E, exageradas, pre- } \\
\text { sumivelmente, em face da lei, as cláusulas contratuais que estabeleçam vantagem que 'restringe } \\
\text { direitos ou obrigaçōes fundamentais inerentes à natureza do contrato, de tal modo a ameaçar } \\
\text { seu objeto ou equilíbrio contratual' ( }\left(\mathcal{} \text {. artigo } 5 \mathrm{I}, \S \mathrm{I}^{\mathbf{9}} \text {, inciso II)." }\right.\end{array}$ \\
\hline
\end{tabular}


Anexo III - Questionário aplicado aos desembargadores

1. Exemplificar uma norma cogente aplicável às relaçōes contratuais para as seguintes áreas:
a) Trabalhista
b) Comercial
c) Direito do Consumidor
d) Meio ambiente
e) Inquilinato
f) Direito Previdenciário
g) Mercado de crédito (e.g., juros)
h) Regulação de serviços públicos

2. Identificar o principal motivo da existência de normas cogentes para cada área relacionada abaixo:
a) Trabalhista
b) Comercial
c) Direito do Consumidor
d) Meio ambiente
e) Inquilinato
f) Direito Previdenciário
g) Mercado de crédito (e.g. juros)
h) Regulação de serviços públicos

3. Identificar, nas áreas acima, a que apresenta a maior e a que apresenta a menor incidência de normas cogentes:

Maior incidência: Menor incidência:

4. Dados demográficos:

Sexo: ( ) M ( ) F

Tempo de Atividade Profissional: anos.

Idade:

5. Definição Política:
( ) Esquerda
( ) Centro-esquerda
( ) Centro
( ) Centro-direita
( ) Direita

6. Partido político com que mais se identifica: (sigla). 